NBER WORKING PAPER SERIES

\title{
INDIA'S EXPERIENCE WITH CAPITAL FLOWS: THE ELUSIVE QUEST FOR A SUSTAINABLE CURRENT ACCOUNT DEFICIT
}

\author{
Ajay Shah \\ Ila Patnaik \\ Working Paper 11387 \\ http://www.nber.org/papers/w11387

\section{NATIONAL BUREAU OF ECONOMIC RESEARCH 1050 Massachusetts Avenue} \\ Cambridge, MA 02138 \\ May 2005
}

This paper is forthcoming in an NBER book to be published by the University of Chicago Press. The views expressed in this paper are those of the authors and not of their employers. We are grateful to CMIE for help on data. We are grateful to Takatoshi Ito, Vijay Kelkar, Joydeep Mukherji, participants of the NBER International Capital Flows conference (December 2004, Santa Barbara) and the NCAER-NBER conference (January 2005, Neemrana) for many ideas and improvements, to Shashank Saksena, H. A. C. Prasad and P. R. Suresh for myriad clarifications about capital controls, to Vikram Nirula of G. W. Capital for facts about call centres, and to Sumanta Basak for outstanding research assistance. The views expressed herein are those of the author(s) and do not necessarily reflect the views of the National Bureau of Economic Research.

(C2005 by Ajay Shah and Ila Patnaik. All rights reserved. Short sections of text, not to exceed two paragraphs, may be quoted without explicit permission provided that full credit, including $(\odot$ notice, is given to the source. 
India's Experience with Capital Flows: The Elusive Quest for a Sustainable Current Account Deficit Ajay Shah and Ila Patnaik

NBER Working Paper No. 11387

May 2005

JEL No. F3

\begin{abstract}
$\underline{\text { ABSTRACT }}$
From the early 1990s onwards, India has engaged in policies involving trade liberalisation, strong controls on debt flows, and encouragement for portfolio flows and FDI, under a pegged exchange rate regime. Domestic institutional factors have led to relatively little FDI and substantial portfolio flows. There has been significant tension between capital flows and the currency regime. Many tactical details of the intricate reforms to the capital controls derive from the interlocking relationships between monetary policy, the currency regime and capital flows. In the recent period, pegging has given a capital outflow through reserves accumulation which was larger than the substantial net private capital inflows. In March 2004, difficulties of pegging appear to have led to a near-tripling of the nominal rupee-dollar returns volatility, which has reduced outward capital flows. The goal of the early 1990s - of finding a consistent way to augment investment using current account deficits - has remained elusive.

Ajay Shah

Ministry of Finance

New Delhi

Ila Patnaik

Indian Express

New Delhi
\end{abstract}




\section{Contents}

1 Introduction 3

2 The quest for a sustainable current account deficit 5

3 Broad empirical features $\quad 6$

4 Currency regime $\quad 8$

5 Capital controls $\quad 10$

5.1 Evolution of capital controls . . . . . . . . . . . . . . . . . . . . 10

5.2 Restrictions on CIP arbitrage . . . . . . . . . . . . . . . . . . . 12

5.3 Capital controls prevalent as of late $2004 \ldots \ldots \ldots \ldots$

6 Investment flows $\quad 17$

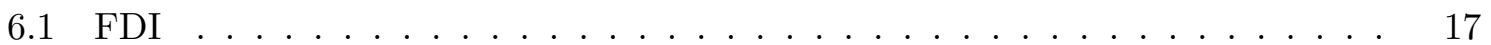

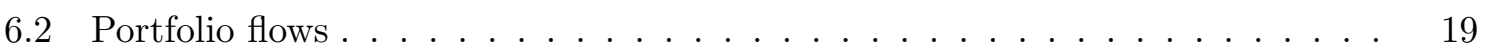

6.2.1 Indian securities in a global portfolio . . . . . . . . . . . . . . . 19

6.2 .2 Factors influencing home bias . . . . . . . . . . . . . . . 20

6.2.3 Growth of net portfolio flows . . . . . . . . . . . . . . 21

6.2.4 FIIs and the domestic equity market . . . . . . . . . . . . . 21

6.3 Determinants of portfolio flows . . . . . . . . . . . . . . . 23

6.4 Evaluating India's experience with the composition of capital flows . . . . . . 24

7 Outward flows owing to reserves accumulation $\quad 24$

8 Implications of the present framework $\quad \mathbf{2 7}$

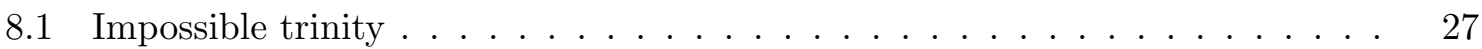

8.2 Volatility of capital flows . . . . . . . . . . . . . . . . 28

8.3 Failure to achieve a current account deficit . . . . . . . . . . . . . . . 29

9 Conclusion $\quad 30$ 


\section{Introduction}

Indian economic policy witnessed a marked shift following a balance of payments crisis in 1991. Prior to this, India had an "LDC style" composition of capital flows, where current account deficits were financed using official flows and debt flows. As in other countries that were liberalising capital flows in this period, the conceptual framework underlying the reforms of the 1990s was based on experiences with volatile debt flows, views about the sustainability of debt flows, and views about a desirable composition of flows.

The new approach, which has been broadly stable from 1992 till 2004, consisted of liberalising the current account, opening up to FDI for domestic and foreign firms, opening up to portfolio flows for foreigners, and restricting debt flows. The currency regime was shifted away from a fixed-but-adjustable exchange rate to a "market determined exchange rate" which was pegged to the USD through extensive trading on the currency market by the central bank.

Indian capital controls consist of an intricate web of a very large number of quantitative restrictions, operated by a substantial bureaucratic apparatus. Liberalisation of FDI and portfolio flows was done in a gradual manner, with a large number of incremental and partial changes to the large number of rules. While some major decisions were taken in 1992, there has been a continual process, which continues even in 2004, of changing restrictions in small steps.

Liberalisation of the current account has been highly successful. Positive technological shocks and dropping prices of international telecommunications helped India obtain high growth rates of services exports. The removal of quantitative restrictions, and the sharp drop in tariffs, served to spur both imports and exports. Through these, gross flows on the current account rose from 25 per cent of GDP in 1992-93 to 35 per cent in 2003-04.

Major changes took place on the capital account also. The policy bias against debt flows led to an outcome where net debt inflows stagnated at roughly 1 per cent of GDP between 1992-93 and 2003-04. Owing to the debt-aversion of the policy framework, gross debt flows actually dropped from $13.5 \%$ of GDP in $1992-93$ to $10.6 \%$ in $2003-04$. Official flows faded into insignificance.

Restrictions on both equity portfolio investors and on FDI were eased in this period. However, net FDI flows into India have remained small, either when compared with Indian GDP or when compared to global FDI flows. In contrast with the Chinese experience, relatively little FDI has come into India in setting up factories which are parts of global production chains. This may be associated with infirmities of Indian indirect taxes and transportation infrastructure. India is more important as a platform for services production as a part of global production chains, where difficulties of indirect taxes and transportation infrastructure are less important. However, services production is less capital intensive, and induces smaller net FDI flows.

Given the size of the Indian economy, and the relative lack of correlation with the global business cycle, Indian equities have had low correlations with global risk factors. In addition, India has fared well in creating the institutional mechanisms of a modern, liquid equity market. Through these factors, portfolio flows have predominated. India's share in global portfolio flows is higher than India's share in global FDI flows, and net portfolio flows are substantial when compared to Indian GDP. 
In many countries, there has been a close interplay between foreign investment and growth in trade. India has increased it's share in world trade without having substantial FDI. One part of an explanation lies in the low capital intensity of export-oriented production. Another aspect is the initial conditions, which consisted of a strong set of domestic firms. Portfolio flows have delivered capital to these domestic firms, which have gone on to obtain growth in exports. The growth of domestic firms has been assisted by relaxations of capital controls which enabled them to engage in outbound FDI, which has served to diminish the size of net FDI flows.

While portfolio flows are sometimes considered volatile, in India's experience, there has been no episode of a significant retreat by foreign investors. Net FDI and net portfolio flows have been fairly stable. Debt flows have been highly volatile, reflecting numerous changes in capital controls applicable on debt flows, and changing currency expectations.

Through these policy initiatives, gross flows on the capital account grew from $15 \%$ of GDP in 1992-93 to $20 \%$ of GDP in 2003-04, along with sharp changes in the composition of flows. In 2003-04, gross portfolio flows amounted to as much as 7\% of GDP.

The growth of the capital account, and the shift towards less government control of the flows, generated increasing difficulties in terms of reconciling currency policy and monetary policy autonomy with the effectively open capital account. Speculative views of the currency were increasingly expressed by economic agents in many ways. Barriers to debt flows blocked currency speculation through debt. There were incentives for currency views to be expressed through other channels of openness available. For example, in this paper, we find that currency expectations were important in explaining the predominantly equity-oriented portfolio flows.

This generated difficulties in implementing the currency regime which had not been experienced prior to liberalisation of the capital account. Resolving these tensions became the defining issue for macro policy. From late 2001 to early 2004, the implementation of the currency regime led to a sharp rise in reserves from $\$ 40$ billion to $\$ 115$ billion. This constituted a substantial outward flow of capital. In 2003-04, net capital inflows of $\$ 21$ billion were accompanied by addition to reserves of $\$ 31$ billion.

In retrospect, India's approach of gradual liberalisation of the capital account has worked well in many ways. India has reaped microeconomic benefits of an open current account, and from FDI and portfolio flows. India has encountered no BOP crisis in the post-1992 period. At the same time, the size of FDI flows has been disappointingly small. Trade and technological sophistication might have grown faster if a more enabling environment had given larger FDI. From the macroeconomic standpoint, there have been episodes where monetary policy autonomy was significantly attenuated in the implementation of the currency regime. One key element of India's original policy quest - the search for a sustainable framework for augmenting investment through current account deficits - has as yet not been achieved.

In this paper, we explore the causes and consequences of the major empirical features of India's experience with capital flows. The paper begins with a review of India's quest for a current account deficit (Section 2), and broad empirical features (Section 3). We review the historical evolution of the currency regime (Section 4) and capital controls (Section 5). We examine FDI and portfolio flows in Section 6, where we also explore the interplay between currency expectations and portfolio flows. Section 7 turns to official flows. We closely examine 200304, where a spurt in capital inflows was accompanied by $\$ 31$ billion of outward flows through 
reserves accumulation. Finally, in Section 8 and Section 9, we discuss some implications of the present framework of capital flows for contemporary macroeconomic policy issues.

\section{The quest for a sustainable current account deficit}

India had low savings rates in the early period, with values of $9.8 \%$ in the $1950 \mathrm{~s}, 12.5 \%$ in the 1960 s and $17.2 \%$ in the 1970s. Economic policy thinking was very aware of the opportunity to use current account deficits, and net capital inflows, in order to supplement domestic savings, augment investment, and thus enjoy a faster growth trajectory.

However, India persistently encountered difficulties in obtaining a sustained and substantial current account deficit. In the late 1970s, a combination of high domestic inflation, a world oil price hike, and a pegged exchange rate generated low exports, a wider current account deficit, and near-exhaustion of reserves. In response to this, India undertook an IMF program in 1981. Conditionalities associated with this program included revision of the exchange rate (Joshi \& Little 1994).

By the late 1980s, India had built up a significant stock of external debt. In a period of political instability in 1990, there was a crisis of confidence, which gave a flight of debt and conditions of a speculative attack on the pegged exchange rate. In response to this, India undertook an IMF program in 1991. Conditionalities associated with this program included revision of the exchange rate, and a shift to a "market determined exchange rate".

In recent years, several prominent documents in policy analysis have advocated larger but sustainable current account deficits:

- From Expert group on commercialisation of infrastructure projects, chaired by Rakesh Mohan, 1996 (page 49):

The sustainability of such economic growth would require continuing high growth in exports, perhaps declining from the current 20 per cent annual growth to about 10 per cent by the end of the next decade, giving an average of about 15 per cent annual growth over the period. If this takes place, total exports should reach about \$66 billion in 2000-01 and $\$ 115$ billion by 2005-06. At these levels, exports would comprise about 15 per cent of GDP in 2000-01 and 17 per cent of GDP by 2005-06, up from the current levels of about 10 per cent. If exports manage to increase to these levels, it would become feasible for India to sustain a wider current account deficit which is required for the non-inflationary absorption of external capital inflows. It is suggested that a sustainable level of current account deficit would increase from the current level of 1.5 per cent of GDP to 2.5 per cent in 2000-01 and 3 per cent in 2005-06. It would then be possible for the net capital inflow to rise from the current level of about $\$ 7$ billion to $\$ 8$ billion to about $\$ 17$ billion to $\$ 20$ billion by 2000-01 and about $\$ 25$ billion to $\$ 30$ billion by 2005-06.

As Table 1 shows, India did better than anticipated. Total exports reached $\$ 118$ billion, or 18.4 per cent of GDP in 2003-04, and net capital inflows reached $\$ 20.5$ billion. However, far from obtaining a larger current account deficit, as had been envisaged in this prominent and influential report, India ended up with a current account surplus of 1.7 per cent of GDP in 2003-04.

- The 10th plan document, which is a medium-term economic policy analysis effort, expresses regrets at the inadequate levels of the current account deficit in recent years 
Table 1 Indian capital flows: 1992-93 versus 2003-04

\begin{tabular}{|c|c|c|c|c|c|c|}
\hline & & 1992-93 & $2003-04$ & \multirow{2}{*}{$\begin{array}{l}\text { Growth } \\
\text { Percent }\end{array}$} & 1992-93 & 2003-04 \\
\hline & & \multicolumn{2}{|c|}{ Billion USD } & & \multicolumn{2}{|c|}{ Percent to GDP } \\
\hline \multicolumn{2}{|c|}{ GDP at market prices } & 239.09 & 639.90 & 9.36 & & \\
\hline \multicolumn{2}{|c|}{ Current account (net) } & -3.53 & 10.56 & & -1.47 & 1.65 \\
\hline \multirow[t]{2}{*}{ Merchandise } & outflows & 24.32 & 80.18 & 11.46 & 10.17 & 12.53 \\
\hline & inflows & 18.87 & 64.72 & 11.86 & 7.89 & 10.11 \\
\hline \multirow[t]{2}{*}{ Invisibles } & outflows & 7.41 & 26.97 & 12.46 & 3.10 & 4.21 \\
\hline & inflows & 9.33 & 52.98 & 17.10 & 3.90 & 8.28 \\
\hline \multicolumn{2}{|c|}{ Capital account (net) } & 3.88 & 20.54 & 16.37 & 1.62 & 3.21 \\
\hline \multirow{2}{*}{ Official flows } & outflows & 2.66 & 6.46 & 8.40 & 1.11 & 1.01 \\
\hline & inflows & 4.92 & 3.34 & -3.47 & 2.06 & 0.52 \\
\hline \multirow[t]{2}{*}{ FDI } & outflows & 0.03 & 1.47 & 42.42 & 0.01 & 0.23 \\
\hline & inflows & 0.34 & 4.89 & 27.25 & 0.14 & 0.76 \\
\hline \multirow[t]{2}{*}{ Portfolio equity } & outflows & 0.00 & 16.86 & 127.46 & 0.00 & 2.64 \\
\hline & inflows & 0.24 & 28.22 & 54.01 & 0.10 & 4.41 \\
\hline \multirow[t]{2}{*}{ Debt } & outflows & 14.99 & 31.01 & 6.83 & 6.27 & 4.85 \\
\hline & inflows & 17.37 & 37.14 & 7.15 & 7.26 & 5.80 \\
\hline \multirow[t]{2}{*}{ Miscellaneous } & outflows & 2.34 & 2.27 & -0.27 & 0.98 & 0.35 \\
\hline & inflows & 1.36 & 5.35 & 13.26 & 0.57 & 0.84 \\
\hline \multirow{2}{*}{\multicolumn{2}{|c|}{$\begin{array}{l}\text { Reserves at year-end } \\
\text { Addition to reserves }\end{array}$}} & 6.43 & 107.45 & 29.17 & 2.69 & 16.79 \\
\hline & & 0.70 & 31.42 & 41.35 & 0.29 & 4.91 \\
\hline \multirow{3}{*}{\multicolumn{2}{|c|}{$\begin{array}{l}\text { Metric of integration } \\
\text { Trade integration } \\
\text { Financial integration }\end{array}$}} & 96.60 & 352.05 & 12.47 & 40.40 & 55.02 \\
\hline & & 59.93 & 224.85 & 12.77 & 25.07 & 35.14 \\
\hline & & 36.67 & 127.20 & 11.97 & 15.34 & 19.88 \\
\hline \multicolumn{7}{|c|}{$\begin{array}{l}\text { "Official flows" comprise external assistance, rupee debt service with respect to Russia, and IMF-related } \\
\text { monetary movements. "Debt" comprises commercial borrowings, short term loans and banking capital. } \\
\text { "Miscellaneous" is the sum of "Other capital flows" and errors \& omissions. } \\
\text { The Indian fiscal year runs from April to March, so 2003-04 runs from } 1 \text { April } 2003 \text { to } 31 \text { March } 2004 .\end{array}$} \\
\hline
\end{tabular}

(Volume 1, paragraph 4.18):

The current account deficit narrowed down and on the average was 0.8 per cent of GDP, less than one half of the 2.1 per cent envisaged in the plan.

There has been considerable discussion about a development strategy where countries might desire current account surpluses (Dooley et al. 2003). In India's case, public statements on development policy were in favour of current account deficits. Many economists have argued that the current account surplus in 2003-04, of 1.7 per cent of GDP, implies a significant opportunity cost in terms of investment foregone and thus lower GDP growth (Lal et al. 2003).

\section{Broad empirical features}

Broad facts about Indian capital flows are presented in Table 1, which shows two years: 199293 and 2003-04. The year 1992-93 was chosen since it reflects the last year of "the previous regime" of highly restricted capital flows. ${ }^{1}$ The year 2003-04 is the most-recent year observed.

\footnotetext{
${ }^{1}$ Significant capital flows through FDI and portfolio investment commenced in 1993-94, which justifies the choice of 1992-93 as the last year of the previous policy regime.
} 


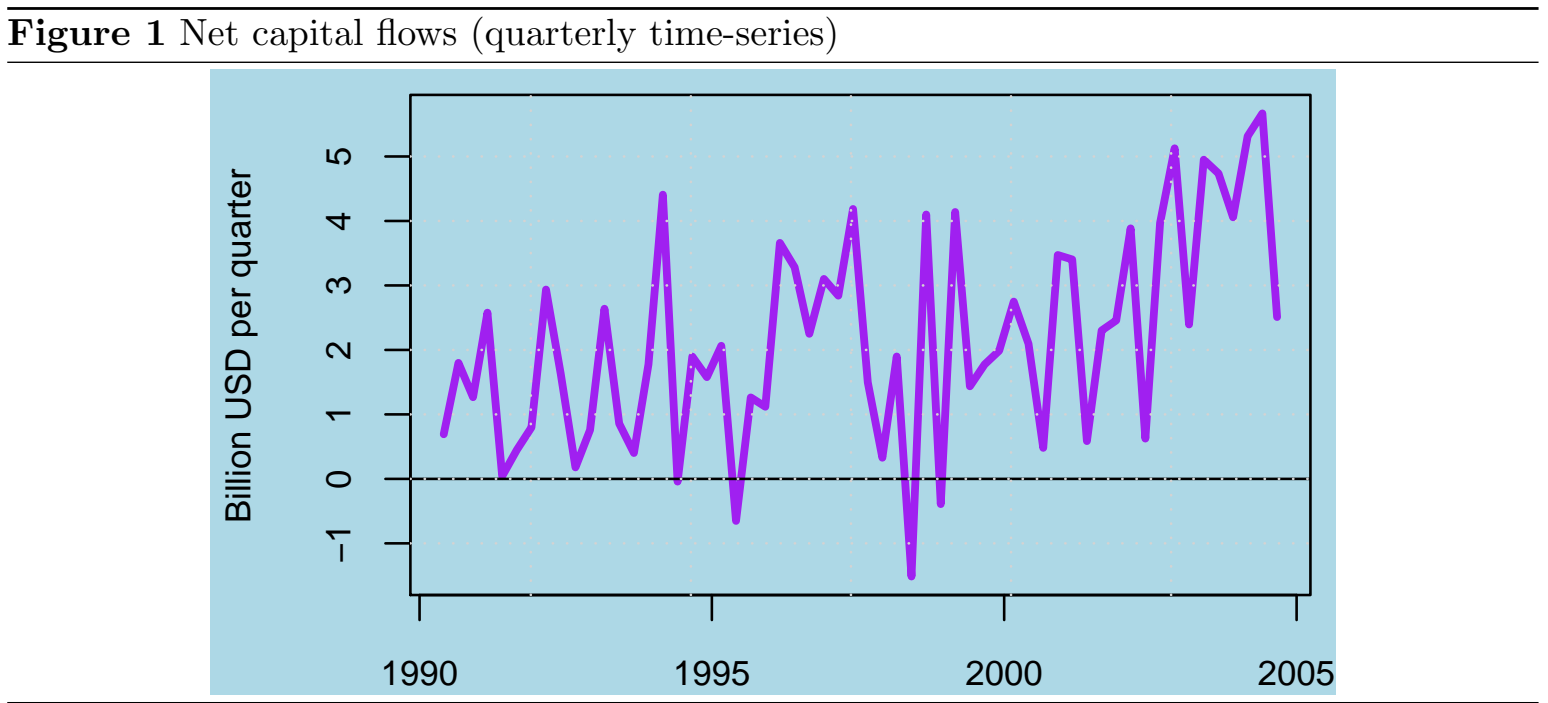

GDP. Over this 11 year period, GDP measured in current dollars grew by an average of 9.4 per cent per annum.

Current account. India undertook major initiatives in trade liberalisation in this period (Panagariya 2005). This led to growth rates of roughly 12 per cent per annum in imports and exports of merchandise, and imports of invisibles. The dropping prices of global telecommunications led to an increase in services exports from India, giving a higher invisibles export growth rate of 17 per cent per annum. Putting these together, trade integration (measured as gross current account flows as percent to GDP) rose sharply from 25.1 per cent of GDP in 1992-93 to 35.1 per cent of GDP in 2003-04 : an increase of 10 percentage points in 11 years. In addition, over this period, the current account switched from a deficit of 1.5 per cent of GDP to a surplus of 1.7 per cent of GDP.

Net capital flows. On the surface, net capital flows appear to have changed little, from 1.6 per cent of GDP in 1992-93 to 3.2 per cent of GDP in 2003-04 (see Figure 1). Yet, major changes took place in the structure of capital flows.

Debt flows In 1992-93, which reflects the previous policy regime, the capital account was dominated by official flows and debt flows. Over this 11 year period, net official flows switched from +0.9 per cent of GDP to -0.5 per cent, and net debt flows stagnated at 1 per cent of GDP. Given the limited accretion of debt, and high exports growth, the debt service ratio dropped from 27.5 per cent in 1992-93 to 18.1 per cent in 2003-04.

FDI and portfolio investment. Major growth was seen in FDI and portfolio investment. Gross flows in these two channels grew sharply from 0.3 per cent of GDP to 8 per cent of GDP. The average annual growth rate of net FDI flows was 24.2 per cent and that for net portfolio flows was 41.9 per cent. Through these high growth rates, over this period, India switched from "LDC style" capital flows, emphasising official flows and debt, to an "emerging market

\footnotetext{
The year-end exchange rate used for 1992-93 incorporates the sharp devaluation which took place when the rupee became a 'market determined exchange rate' in 1992. Hence, 1992-93 is also the first year for which it is meaningful to convert between rupees and dollars, e.g. for the purposes of re-expressing GDP in USD. All values are shown in USD so as to ease interpretation and international comparison, and to avoid noise induced by domestic inflation volatility in this period.
} 
Table 2 Cross-currency volatility (daily returns, 8/1992 - 11/2004)

\begin{tabular}{ccccc}
\hline & USD & GBP & EUR & JPY \\
\hline INR & 0.277 & 0.634 & 0.778 & 0.848 \\
USD & & 0.588 & 0.738 & 0.836 \\
GBP & & & 0.601 & 0.896 \\
EUR & & & & 0.932
\end{tabular}

style" structure of capital flows, emphasising FDI and portfolio investment. Gross flows on the capital account reached 19.9 per cent of GDP in 2003-04, an increase of 4.5 percentage points as compared with 1992-93.

Portfolio flows are more prominent when measuring gross flows on the capital account, since they involve larger two-way flows of capital. In 2003-04, FDI inflows were 3.33 times bigger than FDI outflows, but portfolio inflows were only 1.67 times bigger than portfolio outflows. Hence, even though net flows through portfolio investment were 3.3 times larger than net FDI flows in 2003-04, gross portfolio flows in 2003-04 amounted to 7 per cent of GDP, while gross FDI flows amounted to only 1 per cent of GDP.

Outward flows. These changes were accompanied by a substantial outward flow of capital through purchases of foreign exchange reserves. The year-end reserves rose sharply from 2.7 per cent of GDP in 1992-93 to 16.8 per cent of GDP in 2003-04. In 2003-04 alone, the addition to reserves was 4.9 per cent of GDP. In this year, net capital flows of $\$ 20.5$ billion, and a current account surplus of $\$ 10.6$ billion, were associated with an addition to reserves of $\$ 31.4$ billion.

Global integration. The sum of gross flows on the current and capital account serves as an overall metric of integration into the world economy. This rose by 14.6 percentage points over this 11-year period, from 40.4 per cent in 1992-93 to 55 per cent in 2003-04.

This data and description suggests that the two major features of India's experience with capital flows have been:

- Rapid growth of foreign investment - particularly portfolio investment - accompanied by slow growth of debt flows.

- A substantial extent of outward flows through reserves accumulation.

This paper seeks to shed some light on the causes and consequences of these major features.

\section{Currency regime}

In India, there has been a rich interplay between policies and outcomes on capital flows and the currency regime. According to the RBI, the Indian rupee is a "market determined exchange rate", in the sense that there is a currency market and the exchange rate is not administratively determined. India has clearly moved away from fixed exchange rates. However, RBI actively trades on the market, with the goal of "containing volatility", and influencing the market price. 


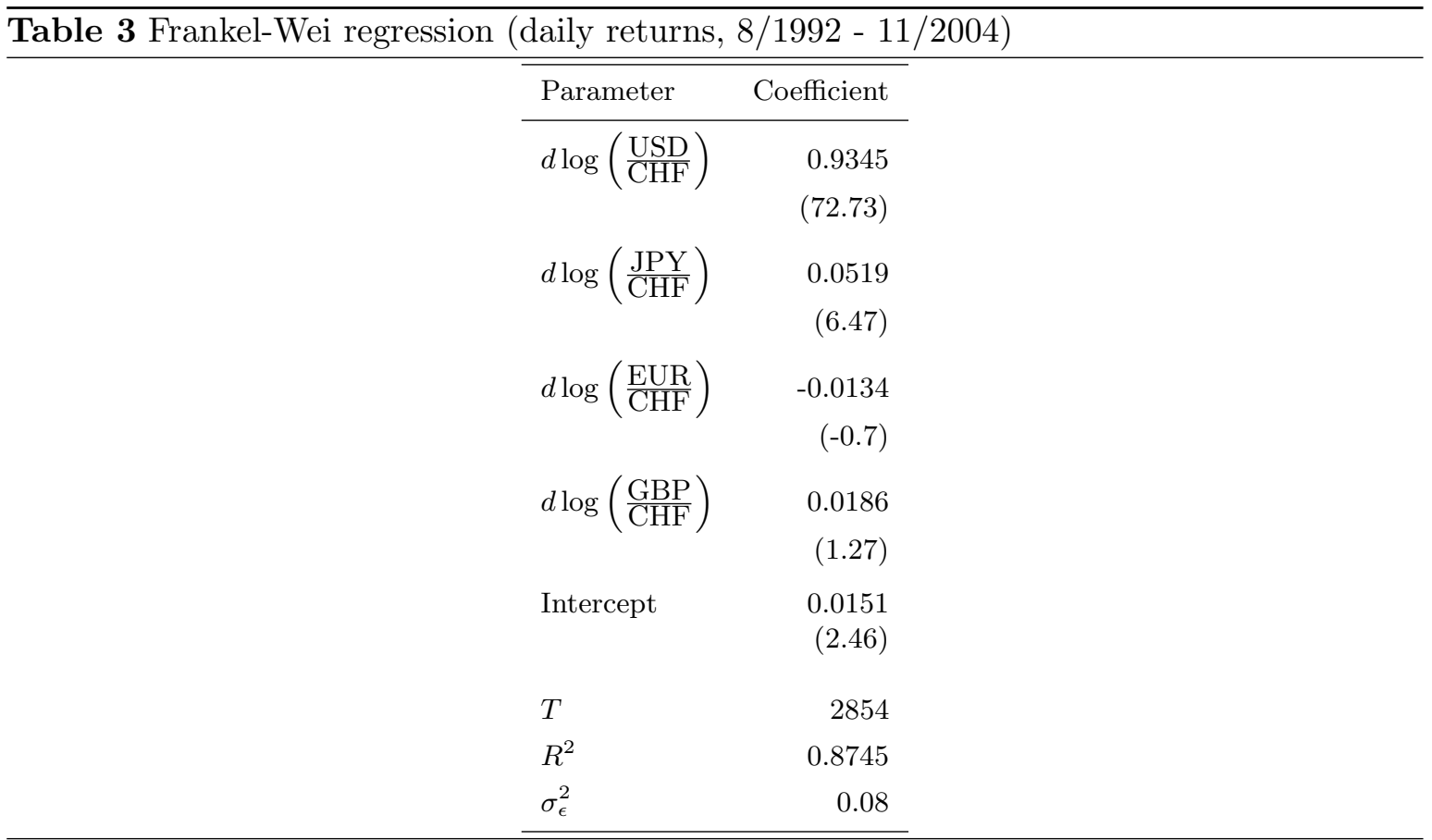

In India, as in most developing countries, there has been a distinction between the de facto and the de jure currency regime. Patnaik (2003) argues that there is a de facto pegged exchange rate, for the following reasons:

- There is extremely low volatility of the INR/USD exchange rate alongside high volatilities of other exchange rates such as the INR/Euro and INR/Yen. Table 2 shows that the volatility of daily returns on the INR/USD has been 0.277 , while (say) the volatility of the INR/JPY has been 0.848 . The latter value is remarkably close to the USD/JPY volatility of 0.836 . In the polar case where the INR/USD were a fixed exchange, the INR/JPY volatility would be exactly equal to the USD/JPY volatility. Volatilities of the rupee against the GBP, EUR and JPY take on large values, similar to those of floating exchange rates such as the USD/EUR or the EUR/GBP.

- Tests based on Frankel \& Wei (1994) show that the USD is overwhelmingly the dominant currency in explaining fluctuations of the Indian currency (Table 3). ${ }^{2}$ The coefficient of the USD/CHF returns is 0.9345 , which is near 1 , while other coefficients are near 0 . The $R^{2}$ of this regression is $87.45 \%$. These facts are consistent with a pegged exchange rate regime.

\footnotetext{
${ }^{2}$ Frankel \& Wei (1994) developed a regression based approach for testing for pegging. In this approach, an independent currency, such as the Swiss Franc (CHF), is chosen as a 'numeraire'. The model estimated is:

$$
d \log \left(\frac{\mathrm{INR}}{\mathrm{CHF}}\right)=\beta_{1}+\beta_{2} d \log \left(\frac{\mathrm{USD}}{\mathrm{CHF}}\right)+\beta_{3} d \log \left(\frac{\mathrm{JPY}}{\mathrm{CHF}}\right)+\beta_{4} d \log \left(\frac{\mathrm{DEM}}{\mathrm{CHF}}\right)+\epsilon
$$

This regression picks up the extent to which the INR/CHF rate fluctuates in response to fluctuations in the $\mathrm{USD} / \mathrm{CHF}$ rate. If there is pegging to the USD, then fluctuations in the JPY and DEM will be irrelevant, and we will observe $\beta_{3}=\beta_{4}=0$ while $\beta_{2}=1$. If there is no pegging, then all the three coefficients will be different from 0 . The $R^{2}$ of this regression is also of interest; values near 1 would suggest reduced exchange rate flexibility.
} 


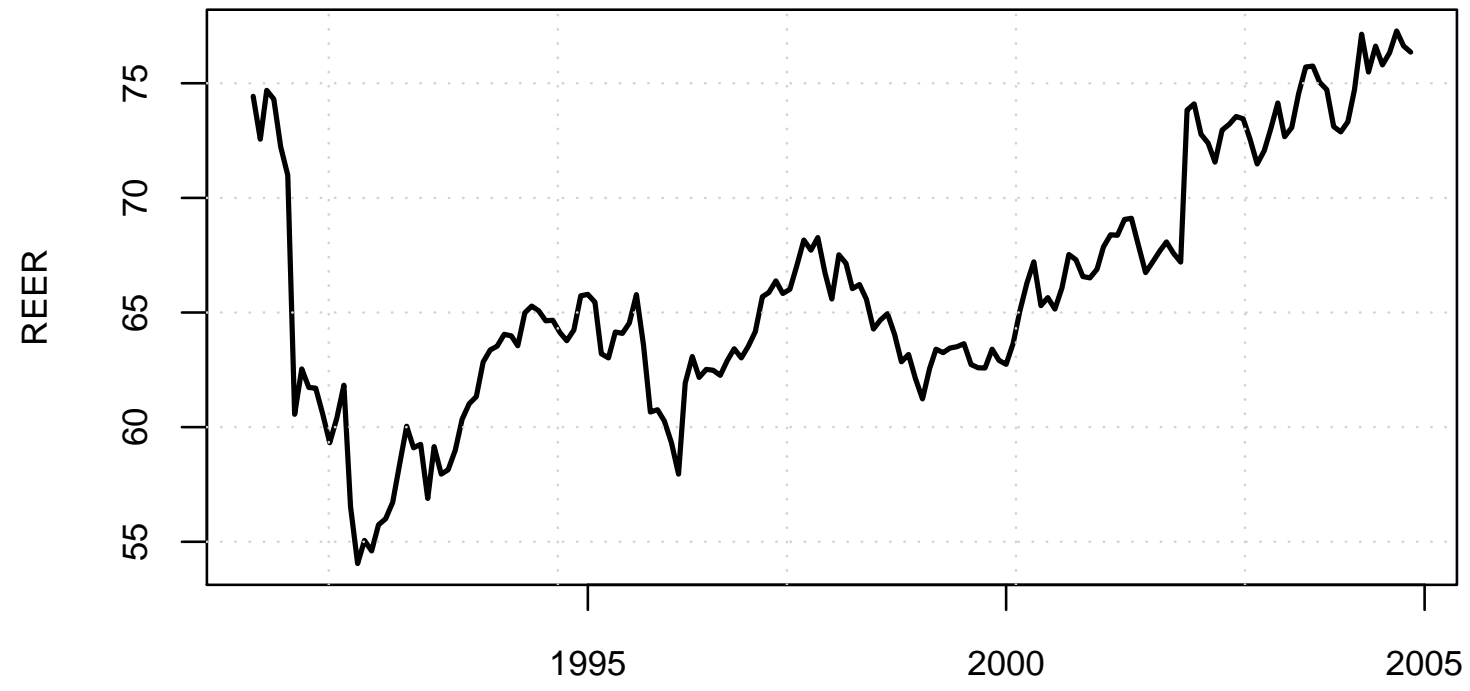

- India's enormous reserves buildup after mid-2002 cannot be explained by a quest for reserves as insurance.

- Extending the Calvo \& Reinhart (2002) $\lambda$ metric of currency flexibility beyond 1999 shows that there has been no change in this metric over 1979-2003.

The extent of pegging has varied through this period. There have been multi-month periods where the INR/USD exchange rate was fixed, but there have also been periods where the volatility of the INR/USD was closer to that of the INR/EUR or the INR/JPY. The facts shown above represent the average behaviour over the period from 8/1992 to 11/2004.

As is typical with pegged exchange rates, significant movements of the real effective exchange rate have taken place (Figure 2).

\section{Capital controls}

\subsection{Evolution of capital controls}

"Foreign institutional investors" (FIIs) were given permissions to participate on the Indian market on 14 September 1992. Limits were placed where no one FII could own more than $5 \%$ of a company, and all FIIs (put together) could not own more than $24 \%$ of a company.

From 1992 onwards, restrictions on portfolio have been steadily eased while preserving sharp constraints on bond investments. Table 4 shows the major events of the 1992-2004 period in the easing of capital controls on portfolio flows. It also gives a flavour of the detailed system of quantitative restrictions operated by the RBI, and the intricate steps through which reform has come about. Through this reforms process, portfolio investors are now able to trade in 
Table 4 Chronology of easing controls on portfolio flows

14 September 1992 "Foreign institutional investors" (FIIs) permitted into the country: these included pension funds, mutual funds, enowments etc. proposing to invest in India as a "broad based funds" with atleast 50 investors and no investor with more than $5 \%$. Permitted access to primary and secondary market for securities, and products sold by mutual funds, with a minimum $70 \%$ investment in equities. Ceiling upon one FII of $5 \%$ ownership of any firm, and ceiling upon total of all FIIs at $24 \%$.

November $1996 \quad$ New concept of "100\% debt FIIs" permitted, which could invest in corporate bonds but not goverment bonds.

4 April $1997 \quad$ Ceiling upon total ownership by all FIIs of local firms raised from $24 \%$ to $30 \%$ (required shareholder resolution).

April $1998 \quad$ FIIs permitted to invest in government bonds, subject to a ceiling upon all FIIs put together of $\$ 1$ billion.

11 June 1998 Ceiling upon ownership by one FII in one firm raised from $5 \%$ to $10 \%$. FIIs permitted to partially hedge currency exposure using the currency forward market. FIIs permitted to trade on the equity derivatives market in a limited way.

August $1999 \quad$ Requirement that FII must have atleast 50 investors eased to 20 investors.

February $2000 \quad$ Foreign firms and individuals permitted access to the Indian market through FIIs as "sub accounts". Local fund managers also permitted to do fund management for foreign firms and individuals through sub accounts. Requirement that no investor can have over $5 \%$ of the FII fund eased to $10 \%$.

1 March $2000 \quad$ Ceiling upon total ownership by all FIIs of local firms raised from $30 \%$ to $40 \%$ (required shareholder resolution).

8 March $2001 \quad$ Ceiling upon total ownership by all FIIs of local firms raised from $40 \%$ to $49 \%$ (required shareholder resolution).

20 September 2001 Ceiling upon total ownership by all FIIs of local firms raised from $49 \%$ to "the sectoral cap for the industry" (required shareholder resolution).

8 January $2003 \quad$ Limitations upon FIIs hedging using the currency forward market removed.

December $2003 \quad$ Twin approvals for FIIs at both SEBI and RBI replaced by single approval at SEBI.

November $2004 \quad$ New ceiling placed upon total ownership by all FIIs of corporate bonds of $\$ 0.5$ billion. 
the spot and derivative markets for both equities and currency. However, the changes in rules have not always been only in the direction of liberalisation.

While considerable openness on FDI exists, there are restrictions on foreign ownership in certain industries. For example, the foreign company engaging in FDI in insurance is limited to a $26 \%$ ownership. Another major constraint influencing FDI is "Press Note 18", whereby a foreign firm which wishes to start a second project in India is required to take approval of its first domestic partner.

In recent years, some databases have sought to reduce the system of capital controls prevalent in a country, at a point in time, into a simple score (Johnston \& Tamirisa 1998). It is instructive to examine their values for India. The IMF single-dummy indices have India as 1 from 1983 to 1995, a period over which major changes took place. Miniane (2004) reports a composite measure based on 14 disaggregated indices, and finds that India moved from 0.917 in 1983 to 0.923 in 2000 (an increase in capital controls). The level and the change in both these indices appears inconsistent with India's experience.

\subsection{Restrictions on CIP arbitrage}

One element of the capital controls consists of barriers to arbitrage on the currency forward market. In an ordinary forward market, arbitrage and only arbitrage defines the forward rate. Even if there are strong speculative views and positions on the market, there is relatively little that can be inferred from forward premium, since this is largely determined by covered interest parity (CIP). ${ }^{3}$ When violations of market efficiency arise, near-infinite capital should come into play in arbitrage. Through this process, arbitrageurs restore market efficiency, and push the forward price back to fair value.

In India, banking regulations place sharp restrictions upon the ability of banks to engage in CIP arbitrage. Importers and exporters are permitted access to the forward market, where they are free to either hedge or to not hedge. The supply and demand for forward dollars by these "permitted hedgers" determines the forward price, and banks are prevented from engaging in CIP arbitrage. This serves to break the link between the spot and the derivative. ${ }^{4}$ In addition, the empirical experience with RBI's trading shows that while RBI

\footnotetext{
${ }^{3}$ The arithmetic of forward pricing in an efficient market is based on 'covered interest parity'. Covered interest parity involves comparing two routes for riskless USD investment. An investor could convert $\$ 1$ into $\left(1+r_{u}\right)^{T}$ through $r_{u}$, which is obtained from the US zero coupon yield curve for $T$ years. Alternatively, the investor could convert into INR at the spot price $S$, invest in the GOI zero coupon yield curve and obtain a locked-in cashflow of $S\left(1+r_{i}\right)^{T} / F$ by converting back into USD at the rate $F$ at date $T$. Under no-arbitrage, these two investment strategies have to yield an identical return, through which the fair value for $F$ can be computed.

${ }^{4}$ Currency derivatives can either trade OTC or on exchange. In India, trading of currency derivatives on exchange is infeasible owing to legal difficulties. Hence, our treatment is limited to currency forwards and does not utilise data from a currency futures market.

Offshore cash-settled forwards, named "Non-deliverable forwards" (NDF) markets" exist on the Indian rupee. However, the mere existence of a currency forward market outside the reach of domestic currency controls is not enough to generate informative prices in the sense of a forward market that is immune to CIP. The essential and unique feature of India's forward market is the restrictions upon CIP arbitrage. If (for example) a forward market existed outside the country, but if arbitrage were feasible, then it would also obey CIP and the prices observed there would be non-informative.
} 
Figure 3 Deviation between actual and fair value of INR/USD forward premium

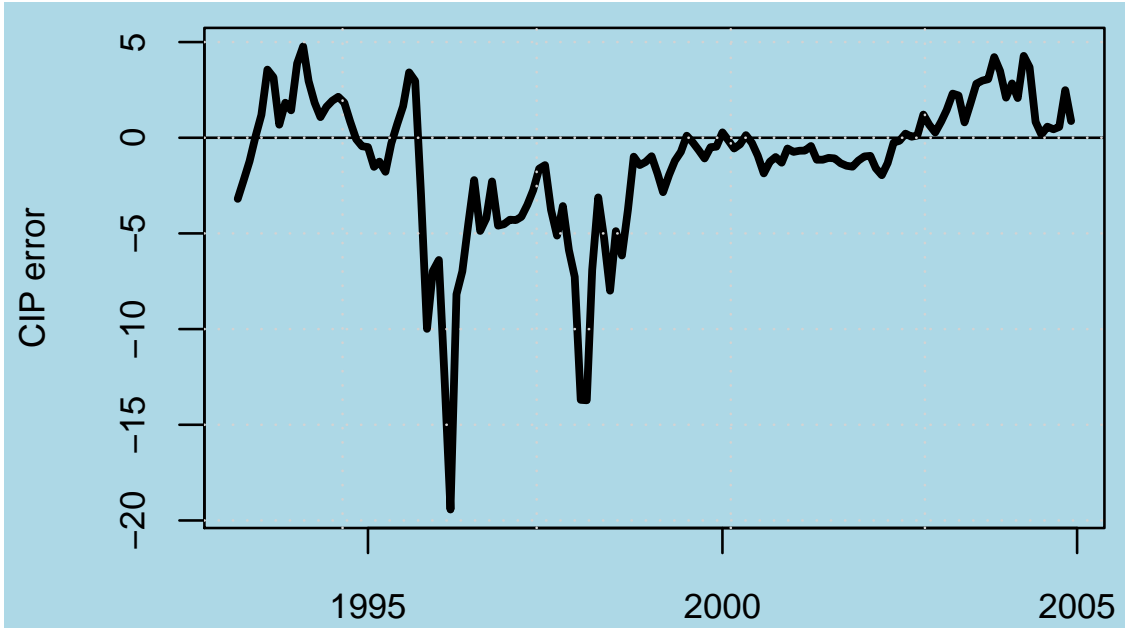

trades extensively on the spot market, the observed forward price tends to be a market determined rate.

As shown in Figure 3, in the INR/USD forward market, deviations from the covered parity condition have tended to persist over multi-month periods. In an unrestricted market, arbitrage would have wiped out such deviations almost instantly.

This situation - where restrictions on CIP arbitrage are coupled with a largely undistorted forward market - have generated a remarkable information source as a side effect. If economic agents expect the rupee to depreciate, there would be a greater interest in selling rupees forward - exporters would stay unhedged, and importers would be likely to hedge. Conversely, if economic agents expect the rupee to appreciate, there would be greater interest in buying rupees forward while those expecting to import would stay unhedged. Lacking adequate arbitrage capital, the forward price does not get restored to the fair value. The deviation between the fair value of the forward premium, and the observed value on the market, then serves as a measure of the speculative views in the market about the future course of the currency. ${ }^{5}$

If arbitrage was unrestricted, the forward premium would not have such an interpretation, and would be relatively non-informative. Under the existing policy framework, the CIP deviation is a uniquely useful high frequency market-based measure of future expectations; one that is not available in most countries where regulators do not inhibit arbitrage. ${ }^{6}$

Given the nature of rules governing importers and exporters, there is little doubt that CIP

\footnotetext{
${ }^{5}$ Apart from conveying expectations of the market, the deviation between the observed forward premium and its fair value also shows the arbitrage opportunity available to the few economic agents who are permitted to engage in the trading required for doing CIP arbitrage. Their mass has - thus far - not been large enough to remove CIP violations.

${ }^{6}$ Internationally, empirical research related to currency expectations uses data based on surveys (Frankel \& Okongwu 1996). Market participants, central bankers, multinational companies and economics departments of banks are interviewed on a weekly or monthly frequency. Survey data such as the Currency Forecasters' Digest, now known as the Financial Times Currency Forecast, forms the basis for a number of papers in the field (Chinn \& Frankel 1994).
} 


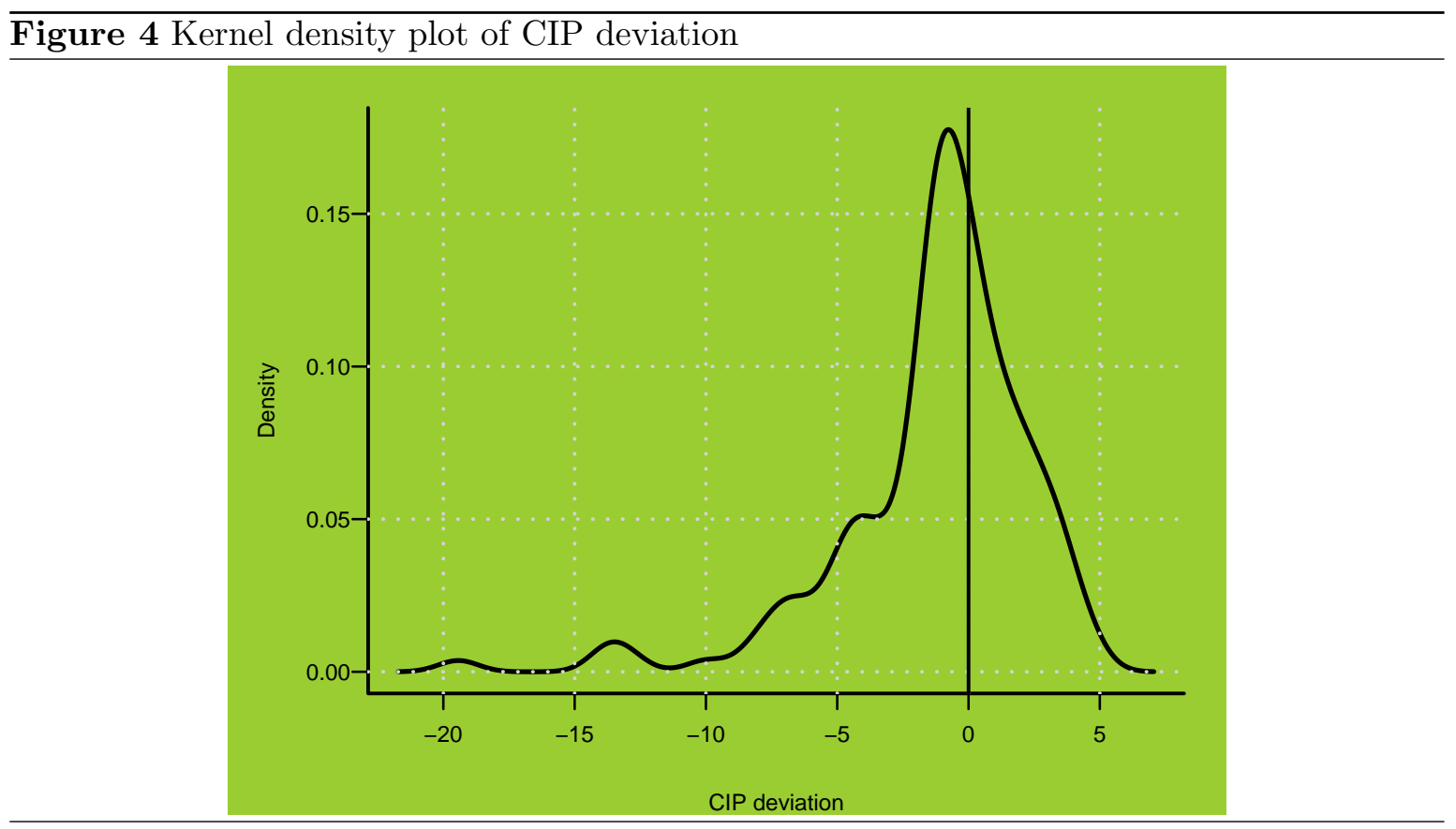

\begin{tabular}{|c|c|c|c|c|}
\hline & OLS & OLS & Robust LS & Robust LS \\
\hline CIP Deviation Lag 1 & $\begin{array}{l}-0.025 \\
(-2.83)\end{array}$ & $\begin{array}{c}0.009 \\
(0.36)\end{array}$ & $\begin{array}{l}-0.023 \\
(-5.21)\end{array}$ & $\begin{array}{r}-0.010 \\
(-0.78)\end{array}$ \\
\hline Lag 2 & & $\begin{array}{l}-0.028 \\
(-0.84)\end{array}$ & & $\begin{array}{r}-0.014 \\
(-0.82)\end{array}$ \\
\hline Lag 3 & & $\begin{array}{r}-0.009 \\
(-0.36)\end{array}$ & & $\begin{array}{r}0.001 \\
(0.05)\end{array}$ \\
\hline$R^{2}$ & 0.019 & 0.024 & & \\
\hline
\end{tabular}

deviations in India reflect the views of economic agents who are given the choice between hedging and not hedging. However, the extent of correctness of these views is a distinct question. An important question concerns the extent to which the speculative views of the market predict future exchange rate movements.

Two specific episodes can be isolated, where the views of the market proved to be wrong. In 1993 and 1994, with strong portfolio inflows, the CIP deviation was strong and positive, suggesting that private agents expected a currency appreciation. However, the RBI chose to effectively have a fixed exchange rate of Rs.31.37, and the expectations of agents proved to be wrong. In late 1997 and early 1998, in the aftermath of the East Asian Crisis, there were strong expectations that the rupee would devalue sharply, giving very large negative values of the CIP deviation (see Figure 3). In the event, domestic interest rates were raised sharply, and the rupee did not devalue, so the expectations of agents proved to be wrong (Patnaik 2005).

We can test the extent to which lagged CIP deviations explain current changes of the exchange rate. If market expectations are (on average) correct, when past values of the CIP deviation are positive, this should be associated with currency appreciation (negative slopes). 
Table 6 CIP deviation as predictor of future currency returns (monthly data)

\begin{tabular}{lrrrr}
\hline & OLS & OLS & Robust LS & Robust LS \\
\hline CIP Deviation Lag 1 & -0.121 & -0.130 & -0.097 & -0.111 \\
& $(-2.42)$ & $(-1.77)$ & $(-3.43)$ & $(-2.67)$ \\
Lag 2 & & 0.171 & & 0.080 \\
& & $(1.91)$ & & $(1.58)$ \\
Lag 3 & & -0.205 & & -0.099 \\
$R^{2}$ & 0.058 & $(-2.78)$ & & $(-2.36)$ \\
\hline
\end{tabular}

A difficulty faced in this regression is the distribution of the CIP deviation (Figure 4), where there are some extreme values (from late 1997 and early 1998). These extreme values for the CIP deviation prove to be influential observations in a regression. Hence, in addition to showing OLS results, we investigate this question using a robust regression using an Mestimator (Venables \& Ripley 2002).

The results for weekly data (Table 5) and monthly data (Table 6) suggest that the CIP deviation at a given point in time is a statistically significant predictor of future currency returns over a considerable future time period. ${ }^{7}$

\subsection{Capital controls prevalent as of late 2004}

The present state of capital controls may be summarised as follows: ${ }^{8}$

Current account There are no current account restrictions, other than the limit upon individuals of purchasing no more than $\$ 10,000$ per year for the purpose of foreign travel.

Restrictions upon the currency market Market access to the currency market is severely restricted, primarily to banks. Only economic agents with a direct current account or capital account exposure are permitted to trade in the market. Exchange traded currency derivatives are absent. Importers/exporters face binding restrictions on the size of their currency forward positions.

Outward flows by individuals Individuals are limited to taking $\$ 25,000$ per year out of the country.

Outward flows by firms Firms are limited to taking capital out of the country which is equal to their net worth.

Borrowing by firms External borrowing by firms must be of atleast 3 years maturity below $\$ 20$ million and of atleast 5 years maturity beyond. Borrowing upto $\$ 500$ million by a firm "for certain specified end-users" - e.g. expanding a factory, or importing capital goods - is allowed without requiring permissions. There is a ceiling whereby approvals

\footnotetext{
${ }^{7}$ These regressions are based on a daily time-series from $1 / 1 / 1997$ till 4/2/2005. The last observed value for the week or the month is used in converting to weekly or monthly frequencies. The simplest model (currency returns on lagged CIP deviation) juxtaposes the currency returns of this month with the CIP deviation prevalent at the end of the last month.

${ }^{8}$ The discussant of the paper, Takatoshi Ito, remarked that these capital controls were reminiscent of Japan in the mid 1960s to the mid 1970s.
} 


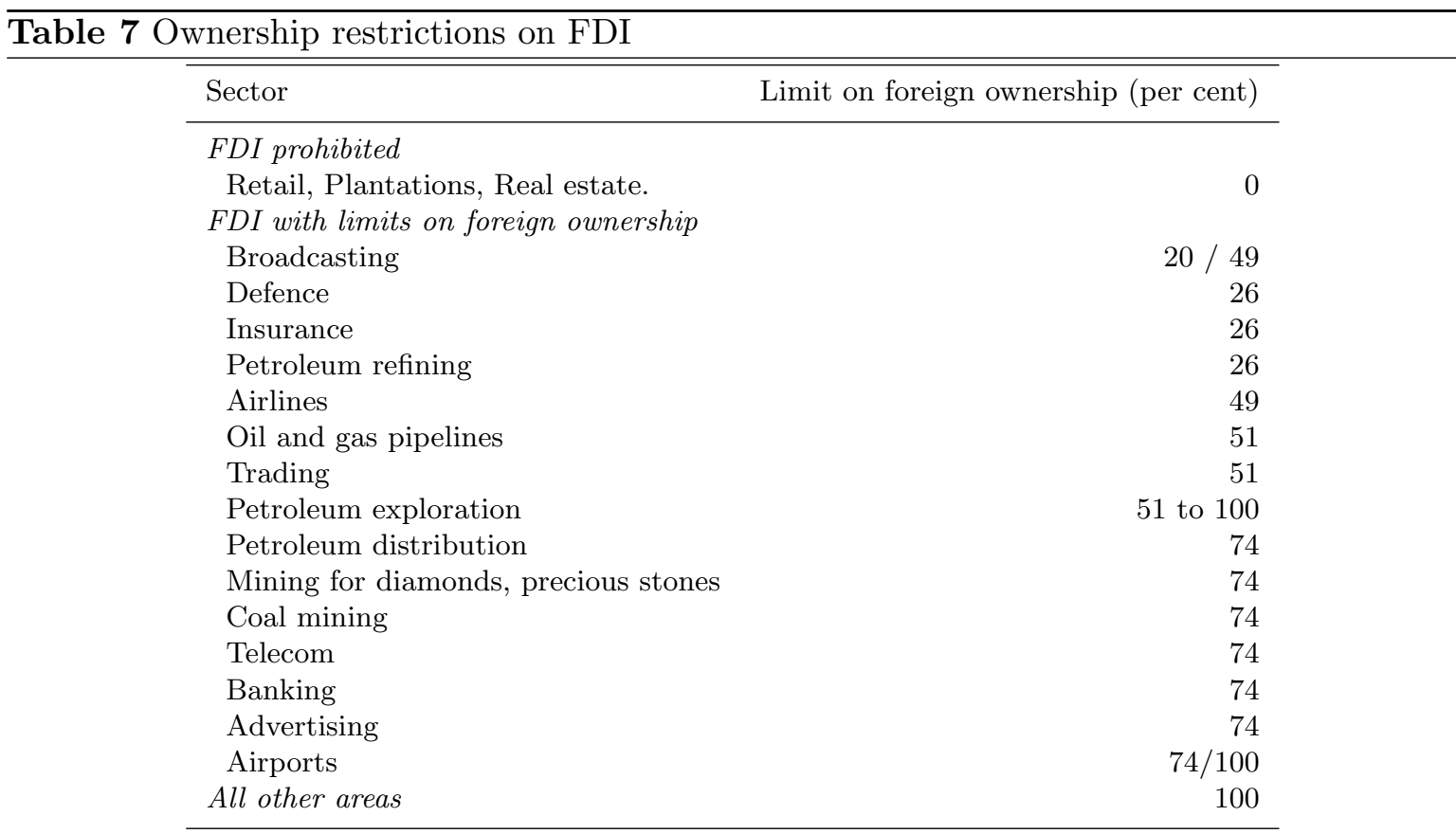

for borrowing by all firms (put together), in a year, should not exceed $\$ 9$ billion per year. This ceiling has never been reached.

Firms are "required to hedge their currency exposure", but there is no mechanism for verifying this, and substantial restrictions on their activities on the currency forward market are in place.

Borrowing by banks The central bank controls the interest rate at which banks borrow from foreigners through "nonresident deposits". 9

Generic restrictions upon portfolio flows Only "foreign institutional investors" are permitted to invest in the country.

Debt investment by foreign portfolio investors The aggregate investment in government bonds by all foreign investors cannot exceed $\$ 1.75$ billion. The aggregate bond investments by any one fund cannot exceed 30\%. The total corporate bond ownership by all foreign investors cannot exceed $\$ 0.5$ billion.

Equity investments by foreign portfolio investors The aggregate foreign holding in a company is subject to a limit that can be set by the shareholders of the company. This limit is, in turn, subject to "sectoral limits" which apply in certain sectors. No one foreign portfolio investor can own more than $10 \%$ of a company. Foreign ownership in certain sectors (telecom, insurance, banking) is capped at various levels. Firms are free to issue GDRs/ADRs outside the country, which can be sold to a broad swathe of global investors. Within these restrictions, foreign investors are fully able to convert currency, hedge currency risk, and trade in the equity spot or derivatives markets.

FDI Foreign ownership in certain sectors (e.g. telecom, insurance, banking) is capped at

\footnotetext{
${ }^{9}$ Gordon \& Gupta (2004) analyses the determinants of nonresident deposits.
} 


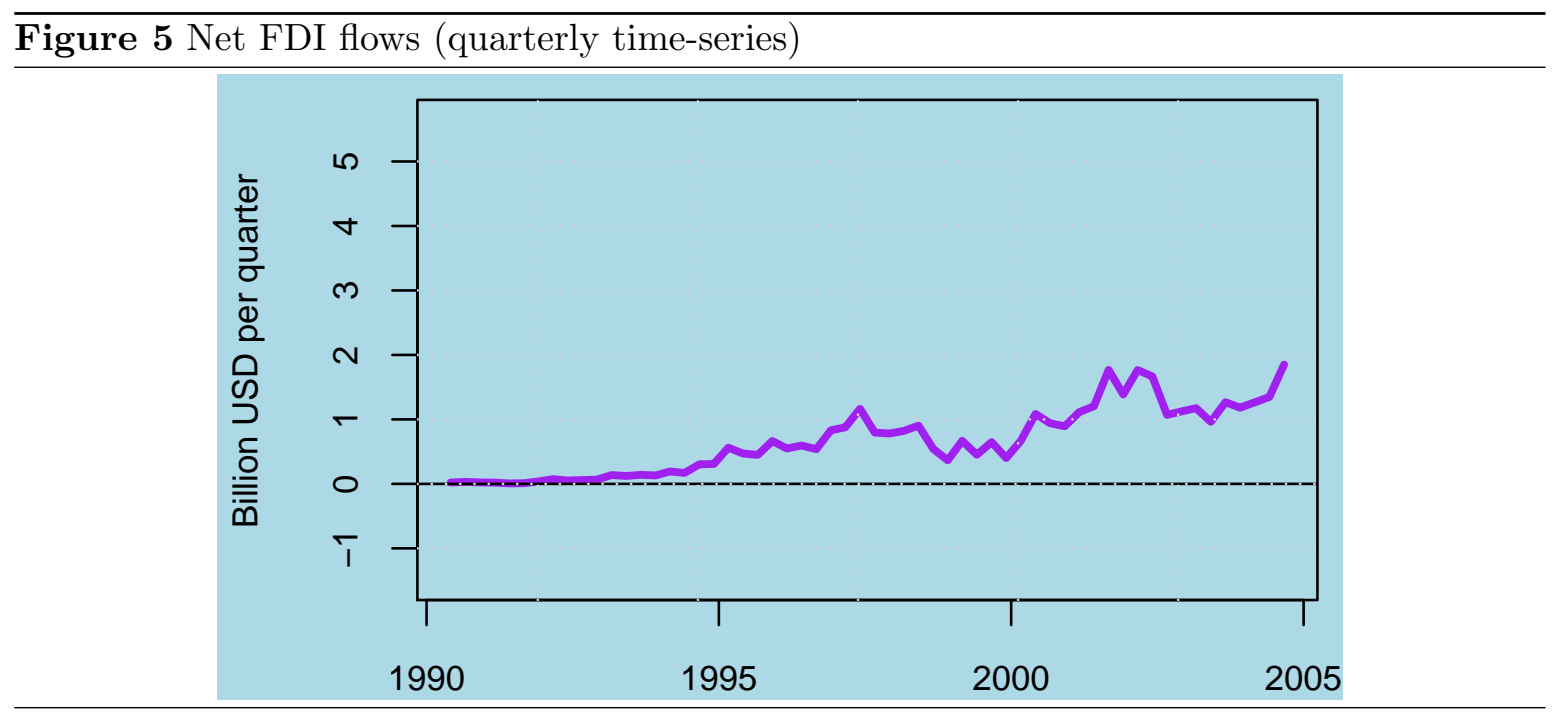

Table 8 Sectoral composition of FDI: 8/1991 to 11/2004

\begin{tabular}{lrr}
\hline Sector & $\begin{array}{r}\text { FDI flows } \\
\text { (Billion USD) }\end{array}$ & Percent to total \\
\hline Oil and electricity & 2.5 & \\
Telecom & 2.7 & 9.8 \\
Transportation & 2.9 & 10.5 \\
Electrical, electronics, software & 3.8 & 11.4 \\
Metals & 0.5 & 15.1 \\
Chemicals & 1.7 & 1.9 \\
Food processing & 1.1 & 6.0 \\
Services & 2.2 & 4.2 \\
Others & 15.0 & 8.2 \\
\hline Total & 32.3 & 32.9 \\
\hline
\end{tabular}

various levels (Table 7). Foreign companies require approval of the first firm they chose to do a joint venture with in the country, if they wish to start a related business.

\section{Investment flows}

\subsection{FDI}

Figure 5 shows the time-series of quarterly flows of FDI. In order to aid comparability, it has the same scale as Figures 1 and 6 .

In many countries, high exports growth has been strongly associated with FDI. As shown in Table 1, India has experienced annual USD growth rates of merchandise exports of 12 per cent and services exports of 17 per cent. Thus, India's share in world trade of both goods and services has been increasing, without having high FDI. Two elements of an explanation might be: 
Table 9 Country composition of Indian trade and FDI

\begin{tabular}{lrr}
\hline Country & Share in FDI & Share in Trade \\
\hline USA & 18.8 & 9.6 \\
Japan & 8.1 & 3.0 \\
Netherlands & 7.7 & 1.0 \\
U.K. & 7.3 & 3.8 \\
Germany & 5.6 & 3.2 \\
\hline
\end{tabular}

FDI share computed 1991-2004, Trade shares over 1998-2004.

Labour intensive exports This may partly reflect the higher extent to which FDI into India has emphasised labour-intensive economic activities, such as services exports. As an example, call centres have a capital output ratio of just $0.75 .{ }^{10}$ Table 8 shows the sectoral composition of FDI, which shows that like the Indian exports basket, FDI has been diversified across a broad range of sectors. The services sector - which includes export-oriented services and domestic services - accounted for only 8.2 per cent of total FDI.

Strength of domestic firms Unlike many emerging markets or transition economies, India had a strong set of domestic firms in place by the 1990s. A steady flow of startups and IPOs has fueled a large domestic corporate sector. These domestic firms were able to engage in export-oriented activities, as opposed to the higher reliance seen in other countries, upon foreign firms who would first bring in FDI and then export. In India's case, the role of foreign capital flows has worked, to a greater extent, through portfolio flows into the domestic equity market, to domestic firms, and thus to exports growth.

Domestic firms have been given an increasingly liberal framework for outward FDI flows, so that they can become multinational corporations. In 2003-04, gross FDI inflows of $\$ 4.89$ billion were accompanied by gross outflows of $\$ 1.47$ billion. Offshore investments by Indian firms made up part of the latter. To this extent, Indian data shows lower net FDI flows.

Table 9 shows the country composition of FDI into India. ${ }^{11}$ In the case of each of the top five countries by FDI share, the FDI share of the country considerably exceeds the trade share of the country. China and UAE are examples of countries where India has substantial trade, but are not sources of FDI to India.

\footnotetext{
${ }^{10}$ The rough financial structure of a 1000 -seat call centre, as of 2004 , is as follows. The project cost is roughly $\$ 15$ million, of which $\$ 10$ million is fixed capital (excluding real estate). The annual revenue works out to roughly $\$ 25$ million, of which the value added is roughly $\$ 20$ million.

${ }^{11}$ These fractions have been computed using the following adjustment. The largest country which sends FDI to India, in the data, is the island of Mauritius (34.5\%). India has an advantageous tax treaty with Mauritius, and many investors choose to incorporate in Mauritius in order to benefit from this tax treatment. The values above show the fraction of countries in the non-Mauritius FDI into India, and are only accurate insofar as the country composition of FDI into India that is routed through Mauritius is the same as the country composition of FDI that comes directly to India.
} 
Table 10 Correlation matrix of some stock market indexes

This uses weekly returns data from $10 / 1995$ to $2 / 2004$. Nifty is the Indian stock market index of the top 50 stocks. Nifty Jr. is the second rung of 50 stocks. Cospi is the encompassing Indian index of all active stocks, which number around 2000. Kospi is the Korean stock market index.

Full period

\begin{tabular}{lrrrr}
\hline & Nifty Jr. & Kospi & Nifty & S\&P 500 \\
\hline Cospi & 0.862 & 0.254 & 0.911 & 0.159 \\
Nifty Jr. & & 0.233 & 0.776 & 0.099 \\
Kospi & & & 0.280 & 0.312 \\
Nifty & & & & 0.221 \\
\hline
\end{tabular}

\begin{tabular}{|c|c|c|c|c|c|c|c|c|c|}
\hline \multicolumn{5}{|c|}{ First half $(10 / 1995-12 / 1999)$} & \multicolumn{5}{|c|}{ Second half $(12 / 1999-2 / 2004)$} \\
\hline & Nifty Jr. & Kospi & Nifty & S\&P 500 & & Nifty Jr. & Kospi & Nifty & $\mathrm{S} \& \mathrm{P} 500$ \\
\hline Cospi & 0.868 & 0.105 & 0.935 & 0.101 & Cospi & 0.863 & 0.424 & 0.892 & 0.209 \\
\hline Nifty Jr. & & 0.101 & 0.803 & 0.023 & Nifty Jr. & & 0.377 & 0.760 & 0.142 \\
\hline Kospi & & & 0.155 & 0.237 & Kospi & & & 0.441 & 0.396 \\
\hline Nifty & & & & 0.169 & Nifty & & & & 0.272 \\
\hline
\end{tabular}

\subsection{Portfolio flows}

\subsubsection{Indian securities in a global portfolio}

In the portfolio optimisation of a globally diversified investor, in a rational setting, the appeal of Indian securities is related to their lack of correlation with global risk factors. Some correlations of weekly returns, in the period from $10 / 1995$ to $2 / 2004$, are in Table $10 .{ }^{12}$

In many small countries, liberalisation efforts in terms of a more open current account, FDI and portfolio flows has led to increased correlations, which has served to diminish the benefits from diversification. In order to explore this issue, Table 10 also breaks the overall period into two halves. The correlation of the overall index (Cospi) against the S\&P 500 doubled from 0.1 in the first half to 0.21 in the second half. However, 0.21 remains a small number by world standards. For example, it is lower than the correlation of Korea's Kospi against the $\mathrm{S} \& \mathrm{P} 500$ in the first half. It is also significantly lower than the Korean correlation of 0.396 in the second half.

These low correlations suggest that Indian equities could play a useful role in improving the Sharpe's ratio of globally diversified portfolios. As an illustrative example, applying a portfolio optimiser to the historical covariance matrix over this period yields weights of $61.6 \%$ for the S\&P 500, $11.5 \%$ for the Korean KOSPI and the remainder in India (19.1\% in Nifty and $7.8 \%$ in Cospi).

\footnotetext{
${ }^{12}$ October 1995 is used as the starting point for this dataset, since it reflects the point by which the early sharp increase in foreign portfolio flows had been completed, and some major changes in the domestic equity market design had been completed. Hence, the period from 10/1995 onwards represents a comparable period.
} 


\subsubsection{Factors influencing home bias}

In a rational world, decisions about including securities from a given country into global portfolios should be based on the improvements in diversification obtained therein. At the same time, a strong problem that is well known in the literature is that of the "home bias", where individual and institutional portfolios tend to hold higher weights of local country securities. In the literature, home bias is believed to be related to informational asymmetries and transactions costs. For example, Portes \& Rey (2001) find that the geography of information rather than the quest for efficient portfolios through diversification - dominates patterns of cross-border equity flows. Other practical constraints include size and liquidity in securities markets of small countries.

India's success on attracting substantial portfolio flows relate to strengths on these issues of information, size and liquidity.

Size: India is a large economy, with a strong set of domestic firms in place by the 1990s when portfolio flows commenced. A steady flow of startups and IPOs has fueled a large domestic corporate sector. As of February 2005, the market capitalisation of the equity market was $\$ 400$ billion.

Information: On the issues of informational asymmetries and transactions costs, India had strengths in terms of a century-old tradition of law, accounting, and stock market trading with extensive participation by domestic households. This implied that many issues about law, information disclosure and corporate governance, which were important to foreign investors, were broadly in place in India before portfolio flows commenced. India's extensive use of English, and the extensive presence of individuals of Indian origin in global finance companies, has helped reduce the informational asymmetry faced by foreign investors. Familiarity with India amongst global finance companies was further heightened from the late 1990s onwards, when most major global finance companies started moving parts of their production process to India, including areas such as call centres, accounting, back office processing, research, and software development.

Liquidity: While the extensive participation by domestic households offered the possibility of a liquid and active stock market, in the early 1990s, there were many weaknesses in the market design, which led to high transactions costs. As a response to these weaknesses, many domestic firms chose to disintermediate the domestic securities markets, and engage in offshore issuance through American Depository Receipts (ADR) or Global Depository Receipts (GDR) markets. This allowed these firms to exploit the superior market design which was available outside in London or New York. However, securities issued outside the country did suffer from poor liquidity owing to the lack of widespread trading interest and incompatible time zone.

Partly as a response to the difficulties faced by foreign investors on domestic stock markets, India embarked on a major program of modifying incentives and institutions on the securities markets (Shah \& Thomas 2000, 2003a). This involved a new securities regulator (SEBI), and a new set of securities trading institutions (NSE, NSCC and NSDL). These institutions innovated on the market design, introducing all the elements of world class securities infrastructure: demutualisation of the exchange (1993), electronic limit order book market (1994), elimination of entry barriers into intermediation (1994), nationwide access (1994), novation at 


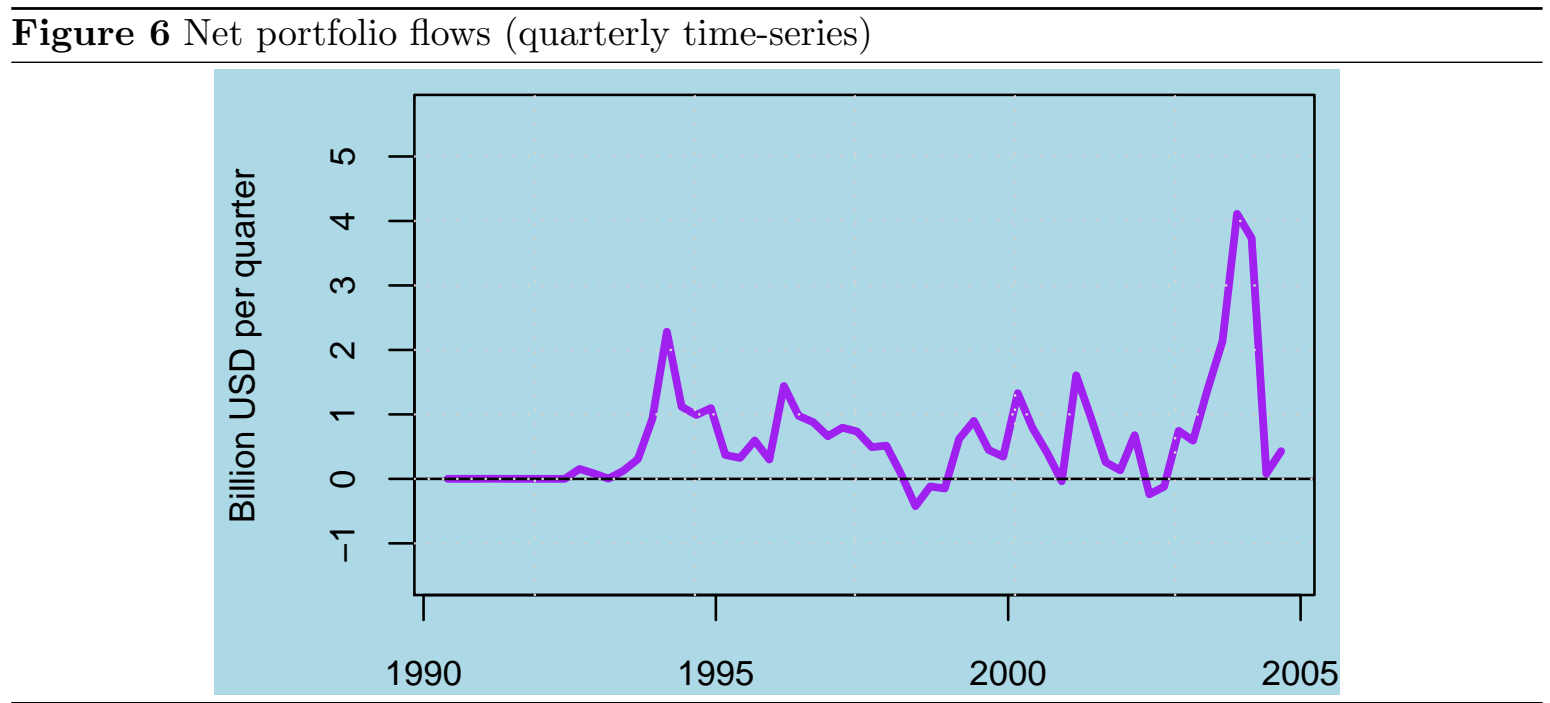

the clearing corporation (1996), dematerialised settlement (1996), equity derivatives trading (2000-2001) and $\mathrm{T}+3$ and then $\mathrm{T}+2$ rolling settlement (2001, 2002).

This reforms program had a profound impact upon transactions costs (Shah \& Thomas 1997). It helped foster IPOs and the growth of market capitalisation, and foreign investment. It also eliminated the rationale for offshore issuance as a mechanism to disintermediate an inefficient domestic market.

In the process of institution building on the securities markets, India harnessed the scale economies associated with a large number of listed companies and a large number of active speculators. The two stock markets in India - NSE and BSE - are ranked 3rd and 5th in the world by the number of transactions. These economies of scale in India were a sharp contrast with the difficulties faced by many small countries in building liquid securities markets (Shah \& Thomas 2003b).

The bond market experienced a very different trajectory in the domestic reforms process, and largely failed to achieve comparable results in terms of liquidity and transparency. However, the prevailing policy environment aimed to discourage debt related flows. Hence, the weakness of the bond market was not a binding constraint in shaping portfolio flows.

\subsubsection{Growth of net portfolio flows}

Figure 6 shows the time-series of quarterly portfolio flows. In order to aid comparability, it has the same scale as Figures 1 and 5. India's share of world portfolio flows considerably exceeds India's share in world FDI flows.

\subsubsection{FIIs and the domestic equity market}

India is a retail-dominated equity market, where institutional investors account for roughly 10.8 per cent of spot market turnover, and just 3.3 per cent of derivatives turnover. Easing capital controls for foreign portfolio investors has given extensive trading by foreign portfolio 
Table 11 Foreign institutional investors on the equity market

$$
\text { (Rs. billion) }
$$

\begin{tabular}{lrrrr}
\hline & \multicolumn{4}{c}{ For calendar year } \\
& 2001 & 2002 & 2003 & 2004 \\
\hline End-year number of FIIs & 490 & 502 & 540 & 637 \\
End-year number of sub-accounts & 1,372 & 1,361 & 1,542 & 1,785 \\
Spot market activity: & & & & \\
$\quad$ Gross buy & 518 & 288 & 944 & 1857 \\
$\quad$ Gross sell & 386 & 253 & 640 & 1467 \\
$\quad$ Net & 131 & 35 & 305 & 390 \\
Derivatives activity: & & & & \\
$\quad$ Gross buy & n.a. & n.a. & n.a. & 842 \\
$\quad$ Gross sell & n.a. & n.a. & n.a. & 861 \\
$\quad$ Net & n.a. & n.a. & n.a. & -19 \\
\hline
\end{tabular}

Table 12 Gross turnover

\begin{tabular}{lrrrr} 
& \multicolumn{4}{c}{ (Rs. billion) } \\
\hline & \multicolumn{4}{c}{ For calendar year } \\
\cline { 2 - 5 } & 2001 & 2002 & 2003 & 2004 \\
\hline Spot market: & & & & \\
$\quad$ NSE+BSE gross turnover & 23416 & 19142 & 26340 & 34168 \\
$\quad$ FIIs & 904 & 540 & 1583 & 3323 \\
Derivatives: & & & & \\
$\quad$ NSE+BSE gross turnover & 838 & 6927 & 28804 & 52118 \\
$\quad$ FIIs & & & & 1703 \\
\hline Equity spot + derivatives & & & & \\
$\quad$ NSE+BSE gross turnover & 24254 & 26070 & 55145 & 86286 \\
FIIs & 904 & 540 & 1583 & 5027 \\
\hline
\end{tabular}

investors. Thus, putting the spot and derivatives markets together, in 2004, FIIs purchased Rs.2699 billion and sold Rs.2328 billion (Table 11). Over the recent four years, the number of registered FIIs has risen from 490 to 637 , and the number of sub-accounts has risen from 1,372 to 1,785 , showing a greater diversity of the foreign investors present.

Derivatives transactions by FIIs were not separately tracked prior to 2004. The inclusion of derivatives data from 2004 onwards overstates the increase in FII turnover for 2004, which hence shows a sharp jump from Rs.1583 billion in 2003 to Rs.5027 billion in 2004. While Rs.5027 billion of gross FII turnover - summing across spot and derivatives markets - appears to be a large number, it now makes up only 5.83 per cent of the overall Indian equity market (Table 12). ${ }^{13}$

\footnotetext{
${ }^{13}$ A key feature of measurement in Table is the use of "gross turnover". Trading volume data, as normally reported by exchanges, shows volume of Rs.100 when one security worth Rs.100 goes from a seller to a buyer. However, when data is captured about the gross trading of market participants, this transaction shows up twice, as Rs.200 of trades. To ensure comparability, the table re-expresses all data as gross turnover, by doubling the trading volume as reported by exchanges.
} 
Table 13 Explaining portfolio flows into the equity market: Monthly data, March 1998 to October 2004

\begin{tabular}{|c|c|c|c|c|}
\hline & Parsimonious & \multicolumn{3}{|c|}{ "Kitchen sink" } \\
\hline Intercept & 238.245 & \multicolumn{3}{|c|}{207.209} \\
\hline CIP deviation & $\begin{array}{r}106.937 \\
(5.26)\end{array}$ & \multicolumn{3}{|c|}{$\begin{array}{c}74.679 \\
(2.09)\end{array}$} \\
\hline Squared CIP deviation & $\begin{array}{r}8.985 \\
(2.10)\end{array}$ & \multicolumn{3}{|c|}{$\begin{array}{l}4.121 \\
(0.76)\end{array}$} \\
\hline US 90-day rate & & \multicolumn{3}{|c|}{$\begin{array}{c}-15.686 \\
(-0.51)\end{array}$} \\
\hline & & Lag 1 & Lag 2 & Lag 3 \\
\hline Lagged Nifty returns & & $\begin{array}{l}-0.350 \\
(-0.06)\end{array}$ & $\begin{array}{r}6.960 \\
(1.18)\end{array}$ & $\begin{array}{r}8.550 \\
(1.47)\end{array}$ \\
\hline Lagged industrial growth & & $\begin{array}{l}-8.061 \\
(-0.24)\end{array}$ & $\begin{array}{r}27.042 \\
(0.88)\end{array}$ & $\begin{array}{r}-4.12 \\
(-0.14)\end{array}$ \\
\hline Lagged S\&P 500 returns & & $\begin{array}{r}5.052 \\
(0.58)\end{array}$ & $\begin{array}{r}9.196 \\
(1.05)\end{array}$ & $\begin{array}{r}4.961 \\
(0.53)\end{array}$ \\
\hline$R^{2}$ & 0.2668 & \multicolumn{3}{|c|}{0.3396} \\
\hline Adjusted $R^{2}$ & 0.2477 & \multicolumn{3}{|c|}{0.2213} \\
\hline
\end{tabular}

\subsection{Determinants of portfolio flows}

Given the prominence of portfolio flows into India, it is important to understand the factors that shape portfolio flows. ${ }^{14}$ In the literature on portfolio flows into emerging markets, evidence has been found about the importance of the US interest rate and flows into equityoriented fund managers in the US. If foreign fund managers react to information in India with a lag, then lagged output and lagged stock returns should help predict portfolio inflows. If decisions of foreign fund managers are shaped by expectations about the currency, then the CIP deviation should help predict portfolio inflows. ${ }^{15}$

Portfolio flows into government bonds are highly restricted by India's capital controls. Hence, we focus on portfolio flows into the equity market. Table 13 shows two OLS regressions which explain portfolio flows into the equity market. The timespan available is short, from March 1998 till October 2004. None of the explanatory variables are significant in the "kitchen sink" model, other than the CIP deviation. The parsimonious model is a quadratic in the CIP deviation, where bigger flows come into the equity market when the currency is expected to appreciate, with a nonlinearity in response where bigger deviations induce bigger inflows.

These results suggest that in India's short experience, traditional explanatory variables appear to be relatively less important, and that currency expectations do play a role in shaping portfolio flows into the equity market.

\footnotetext{
${ }^{14}$ This question has been recently addressed by Gordon \& Gupta (2003).

${ }^{15}$ As of late 2004 , the Indian $r_{f}$ was $4.5 \%$, the historical equity premium was roughly $8 \%$ and the annualised volatility of the equity index was roughly $20 \%$. The Sharpe's ratio of the equity index - as viewed by a foreign investor - would hence be significantly affected by currency views of (say) $\pm 5 \%$.
} 


\subsection{Evaluating India's experience with the composition of capital flows}

India represents a striking example of a developing country where portfolio flows have been particularly important, with net portfolio flows presently running at roughly three times the size of net FDI flows. India's experience is hence important from the viewpoint of the literature on composition of capital flows.

Where many economists have argued in favour of FDI given that FDI is "bolted down" and cannot flee in the event of a crisis, recent research has brought new perspectives to bear on this question. Hausmann \& Fernandez-Arias (2000) find that when countries develop, while total capital flows go up, the share of FDI in capital flows goes down. They argue that portfolio flows require more sophisticated institutions and a greater degree of trust on the part of the investor, and that a domination of FDI is found in countries with the weakest institutions. In addition, Fernandez-Arias \& Hausmann (2000) argue that FDI is not necessarily "bolted down", that a firm faced with a currency crisis can find many instrumentalities to take capital out, such as borrowing in the country against physical assets as collateral, and taking financial capital out of the country. In this context, Bird \& Rajan (2002) offer striking evidence from Malaysia. In the period from 1990 to 1997, Malaysia had no portfolio inflows, and FDI dominated their capital inflows. Yet, Malaysia went on to experience a currency crisis.

The Indian experience is interesting from the viewpoint of this debate. India represents an important example of a country where sophisticated institutions have helped obtain high success in attracting portfolio flows.

\section{Outward flows owing to reserves accumulation}

As argued in Section 3, a major feature of India's recent experience with capital flows has been the outward flows of capital taking place owing to purchase of reserves. The recent experience with the stock of reserves and the flow of net purchases by the RBI on the currency market is shown in Figure 7 and Figure 8.

This shows a striking buildup of reserves, from roughly $\$ 40$ billion to $\$ 115$ billion, over the period from late 2001 to early 2004. Through this period, RBI purchases on the currency market went up to $\$ 7$ billion in April 2004. Patnaik (2003) argues that this reserves buildup was related to implementing the currency regime. Trading by RBI on the currency market, and the change in reserves, understates the extent of outward capital flows, since many other decisions were also taken in order to help sustain the currency regime which were associated with outward capital flows and reduced inward flows. These included prepayment of loans of the government, through which the net capital flows on account of "Official flows" in 2003-4 seen in Table 1 show an outward flow of $\$ 3.12$ billion.

Through this period, India experienced current account surpluses. This was a paradoxical turnaround compared with the starting point of the reforms. A goal of the early reforms was to find a sustainable mechanism to sustain the import of capital, i.e. a current account deficit. By 2002, India found itself in a situation with persistent export of capital, which raised concerns about the adverse impact on GDP growth (Lal et al. 2003). 
Figure 7 Foreign currency reserves

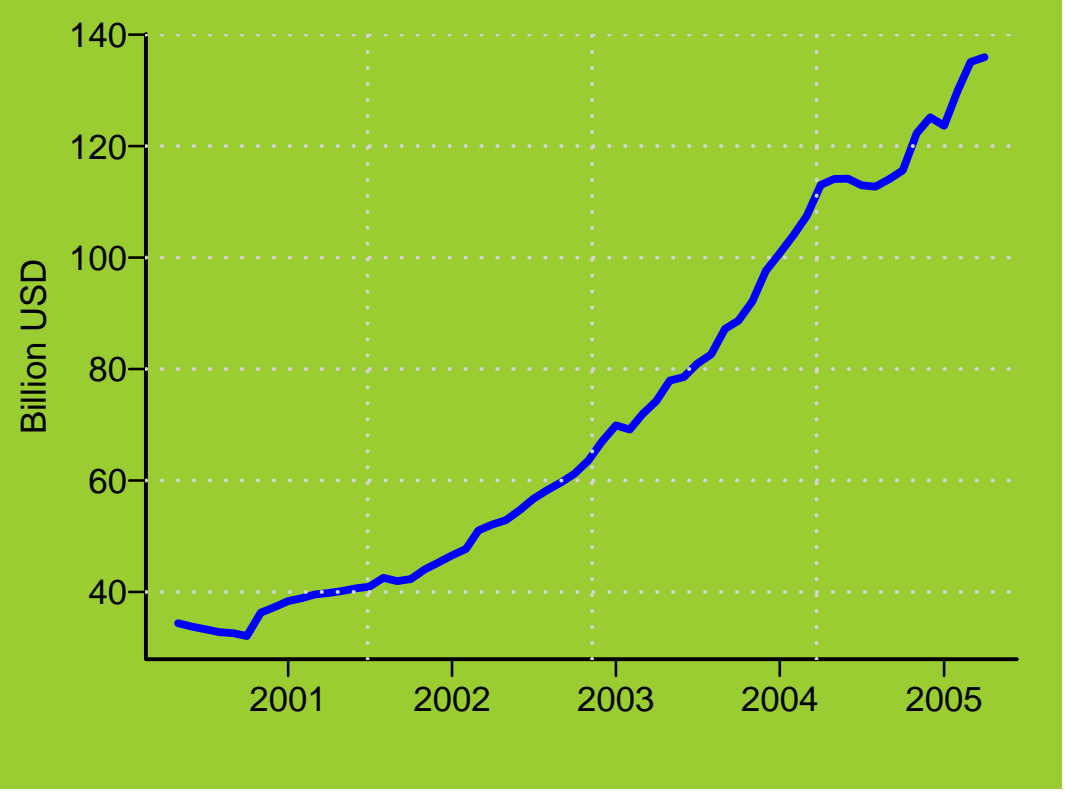

Figure 8 RBI purchases on the currency market

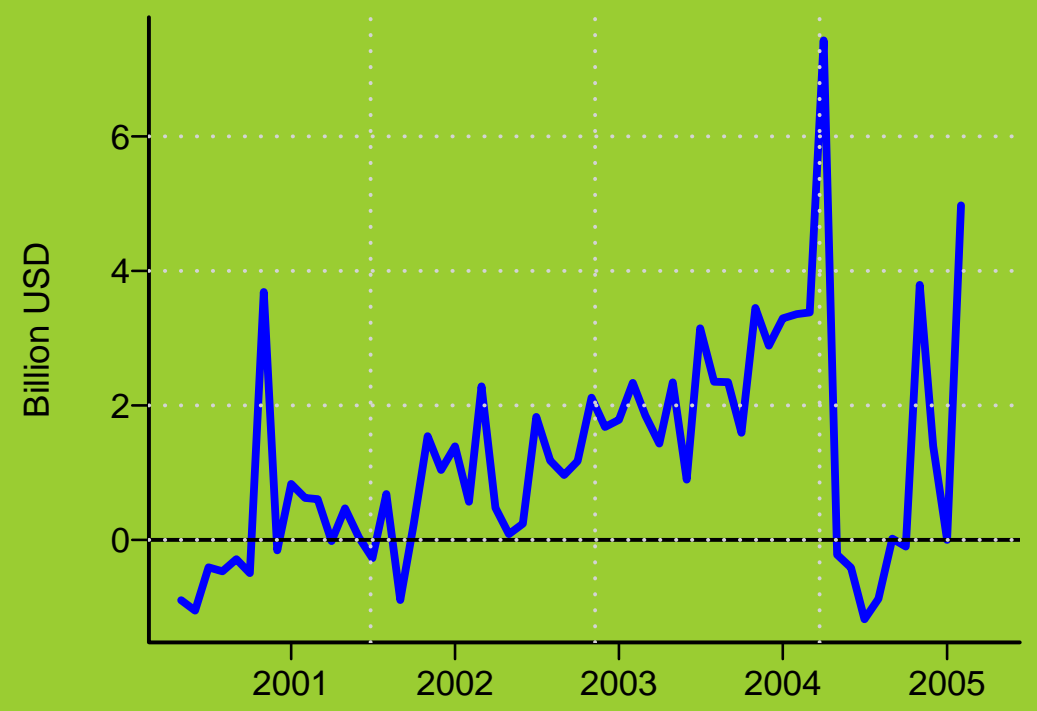




\begin{tabular}{crr}
\hline Table 14 The rupee-dollar exchange rate, 9 March to 5 April 2004 \\
\hline \multicolumn{1}{l}{ Date } & INR/USD & Returns (\%) \\
\cline { 2 - 3 } $2004-03-09$ & 45.21 & -0.09 \\
$2004-03-10$ & 45.23 & 0.04 \\
$2004-03-11$ & 45.25 & 0.04 \\
$2004-03-12$ & 45.27 & 0.04 \\
$2004-03-15$ & 45.25 & -0.04 \\
$2004-03-16$ & 45.24 & -0.02 \\
$2004-03-17$ & 45.25 & 0.02 \\
$2004-03-18$ & 45.22 & -0.07 \\
$2004-03-19$ & 45.22 & 0.00 \\
$2004-03-22$ & 45.15 & -0.15 \\
$2004-03-23$ & 44.93 & -0.49 \\
$2004-03-24$ & 44.76 & -0.38 \\
$2004-03-25$ & 44.75 & -0.02 \\
$2004-03-26$ & 44.73 & -0.04 \\
$2004-03-29$ & 44.12 & -1.37 \\
$2004-03-31$ & 43.39 & -1.67 \\
$2004-04-02$ & 43.77 & 0.87 \\
$2004-04-05$ & 43.67 & -0.23 \\
\hline
\end{tabular}

An equally interesting feature of India's experience was the period from mid-March 2004 onwards, where currency trading by the RBI, and hence the reserves accumulation, slowed down. Table 14 shows the small daily fluctuations of the INR/USD rate going upto 19 March 2004 , and the larger volatility from that date on. The first nine days shown in this table had a zero change in the exchange rate; the second nine days shown had a appreciation of 3.4 per cent. In the period from $1 / 1 / 2000$ till $19 / 3 / 2004$, daily INR/USD returns had a volatility of 0.129 per cent. For some of the following months, (22/3/2004 till 11/2/2005), the volatility had nearly tripled, to 0.355 . This suggests that there may have been a change in the currency regime for the period after 19 March 2004, leading to a drop in outward capital flows through purchase of reserves. Across these events, however, no change in the currency regime was officially announced.

Even in months where little trading was done by RBI, reserves continued to fluctuate owing to the currency composition of the portfolio, and returns are earned on the fixed income instruments in which reserves are invested. ${ }^{16}$ In addition, the period after May 2004 was one where the USD depreciated significantly against the Euro. Since India held significant Euro denominated assets, but reported foreign currency reserves in USD, this showed up as higher reserves.

\footnotetext{
${ }^{16}$ India does not disclose the currency composition of the reserves portfolio. On 30 April 2004, disclosures under the IMF Template on International Reserves showed that of the reserves portfolio of $\$ 113$ billion, $\$ 40$ billion were held as securities, and $\$ 72.9$ billion were held as "Currency and deposits". Of the securities portfolio, the US Treasury disclosure system (Sobol 1998) (http://www.ustreas.gov/tic/mfh.txt) showed that in December 2004, India had $\$ 12.9$ billion of US government bonds.
} 


\section{Implications of the present framework}

\subsection{Impossible trinity}

As highlighted in Table 1 early in this paper, the size of the current account and the capital account rose sharply from 1992-93 to 2003-04. Gross flows on the current account, expressed in USD, grew at a compound rate of 12.77 per cent per annum, and gross flows on the capital account grew at a similar rate of 11.97 per cent per annum. Both these growth rates were faster than the growth of GDP expressed in nominal USD of 9.36 per cent per annum. Hence, the overall measure of integration rose sharply from 40.4 per cent of GDP in 1992-93 to 55 per cent in 2003-04.

Under these conditions, considerable movements of capital can take place in response to speculative views about the currency. As an example, the regression results of Table 13, CIP violations are an important explanatory variable in the model for portfolio flows.

The year 2003-04 serves as a valuable illustration of how capital flows would behave under conditions where the currency regime left significant opportunities for speculative trading on the currency. Going beyond the current account, FDI and portfolio flows, even under the constraints in place in India, debt flows can also play a role in currency speculation. It is striking to notice that in 2003-04, debt flows worked out to roughly $\$ 6$ billion out of total net capital flows of $\$ 20$ billion.

Finally, it is well known in the literature on capital controls that the current account can be used for implementing capital movements and currency speculation, through overinvoicing, underinvoicing, prepayment, and delayed payments (Patnaik \& Vasudevan 2000). These issues have become more pertinent, given the sharp rise in the size of the current account, from $25 \%$ of GDP in $1992-93$ to $35 \%$ in $2003-04$.

These arguments suggest that the impossible trinity is an increasingly important constraint faced by Indian macro policy (Joshi 2003). Patnaik (2005) examines how monetary policy was attenuated through implementation of the currency regime in two prominent episodes in the recent 11-year period.

As outlined in Section 7, the pressures in implementing the pegged exchange rate were heightened in 2003 and 2004, and while no public announcement has been made about a change in the currency regime, nominal rupee-dollar volatility rose significantly from $0.129 \%$ per day in some months to $0.355 \%$ per day in other months.

India continues to grapple with the tradeoffs associated with the impossible trinity. On 12 January 2005, the head of the central bank proposed that India should re-examine the existing framework of capital controls, and possibly introduce a fresh set of restrictions including quotas or ceilings on portfolio flows, enhancing "quality of flows" by restrictions upon eligible foreign investors, price-based measures such as taxes, and monitoring and restrictions upon voting rights of non-residents. While no decisions were taken to introduce such capital controls, the speech highlights the tensions faced in Indian macro policy, and the difficulties faced in the existing combination of a pegged exchange rate and a fairly open capital account. 
$\overline{\text { Table } 15 \text { Volatility of capital flows : summary statistics of quarterly data in million USD, }}$ from Q1/1995 to Q2/2004

\begin{tabular}{lrrrrrr}
\hline & Minimum & $\begin{array}{r}25 \text { th } \\
\text { percentile }\end{array}$ & Median & $\begin{array}{r}75 \text { th } \\
\text { percentile }\end{array}$ & $\begin{array}{r}\text { Maximum } \\
\text { Inter-quartile } \\
\text { range }\end{array}$ \\
\hline Raw data & & & & & & \\
Portfolio & -423 & 260 & 594 & 899 & 4111 & 624 \\
FDI & 365 & 595 & 886 & 1175 & 1768 & 564 \\
Debt & -1257 & 270 & 826 & 2330 & 3895 & 1825 \\
Official & -2657 & -738 & -24 & 210 & 857 & 921 \\
\hline Total & -1514 & 1436 & 2426 & 3969 & 5315 & 2496 \\
\hline Residuals about time trend & & & & & \\
Portfolio & -1278 & -531 & -19 & 311 & 2903 & 246 \\
FDI & -534 & -137 & -26 & 115 & 666 & 1806 \\
Debt & -2448 & -826 & -230 & 1083 & 2833 & 1017 \\
\hline Official & -2249 & -555 & 261 & 511 & 1214 & 2018 \\
\hline Total & -3648 & -771 & 224 & 1317 & 2340 & \\
\hline
\end{tabular}

\subsection{Volatility of capital flows}

As argued above, India's stance on liberalisation of the capital account was strongly motivated by certain priors about the volatility of capital flows, and about the extent to which different kinds of capital flows would impinge upon implementation of the prevailing currency regime. In the literature, there has been disagreement about the volatility of the various kinds of capital flows, and the interplay between the currency regime adopted and the volatility of certain kinds of capital flows. ${ }^{17}$

We can use quarterly BOP data in order to review India's experience with volatility of the four components of capital flows. In order to avoid the formative period, we focus on the period after 1995. This helps us obtain information about the behaviour in the post-reform period.

Table 15 shows summary statistics about the four components of net capital flows, using data for 37 quarters from the Q1/1995 to Q2/2004. Since the data often has unusual distributional characteristics, the interquartile range is used as a relatively nonparametric measure of dispersion. ${ }^{18}$

The raw data show that a net outflow was never observed in the case of FDI. FDI and Portfolio flows have similar values for the inter-quartile range. Debt and official flows seem to be much more volatile than FDI and portfolio flows.

When expressed as residuals about a time trend, all four components have experienced significant negative outflows in the worst quarter. Viewed in this fashion, FDI flows seem to be

\footnotetext{
${ }^{17}$ In Asia, in the decade of the 1990s, (Alfaro et al. 2004) find that in Asia, the volatility of capital flows has been 1.2 for FDI, 15.4 for portfolio equity flows, and 1.6 for debt. They define "volatility of capital flows" as the standard deviation of per capita net capital flow divided by the average of gross inflow and gross outflow.

${ }^{18}$ The prob values obtained using the Shapiro-Wilk test of normality for the five time-series are : Portfolio $\left(4.672 \times 10^{-6}\right)$, FDI (0.081), Debt (0.035), Official (0.0018) and Total (0.57). Hence, we avoid the use of the standard deviations as a measure of dispersion.
} 
Table 16 Saving, Investment, Current account deficit

\begin{tabular}{lrrr}
\hline \multicolumn{1}{l}{ Year } & Savings & Investment & Current account balance \\
\hline $1995-96$ & 25.1 & 26.9 & -1.7 \\
$1996-97$ & 23.2 & 24.5 & -1.2 \\
$1997-98$ & 23.1 & 24.6 & -1.4 \\
$1998-99$ & 21.5 & 22.6 & -1.0 \\
$1999-00$ & 24.2 & 25.3 & -1.0 \\
$2000-01$ & 23.7 & 24.4 & -0.6 \\
$2001-02$ & 23.4 & 22.6 & 0.7 \\
$2002-03$ & 26.1 & 24.8 & 1.2 \\
$2003-04$ & 28.1 & 26.3 & 1.7 \\
\hline
\end{tabular}

highly stable, and more stable than other components. The ranking of volatility of components, when viewed in this fashion, appears to be Debt $>$ Official $>$ Portfolio $>$ FDI.

Over this period, fluctuations in debt and official flows frequently reflected changes in the policy framework. Capital controls and other policy levers were regularly used to encourage or discourage debt and official flows, depending on the tactical exigencies of implementing the currency peg. On some occasions, offshore borrowing was effectively initiated by the government, and banks were encouraged to borrow abroad high rates (set by RBI). At other times, strict controls have been placed on offshore borrowing, and the interest rate at which banks borrow has been cut (Gordon \& Gupta 2004). Hence, there is a need for caution in interpreting the characteristics seen therein, which may reflect factors such as policy volatility and currency expectations. The volatility of debt flows and of official flows might have been very different if India's policies on capital controls had been stable, or if the currency regime had been different.

The results for the volatility of India's portfolio and FDI flows appear to be more meaningful, since they reflect the outcomes obtained under a broadly stable policy framework, subject to a steady process of liberalisation whereby controls have been slowly relaxed over the years, with an essentially one-way direction of reforms.

\subsection{Failure to achieve a current account deficit}

As emphasised in Section 2, India has long sought to augment domestic savings using capital flows so as to achieve a higher investment rate. As argued above, the currency regime chosen by India led to a failure to achieve this goal, despite a considerable success in attracting sustained capital flows.

Table 16 shows how from 1995-96 to 2003-04, India lost 3.4 per cent of GDP of an investment rate owing to the change in the current account balance. In the table, the savings rate rose strongly by 3.0 percentage points of GDP over an eight year period, but the investment rate actually dropped by 0.6 percentage points of GDP. 


\section{Conclusion}

India serves as an interesting case study in integration into the world economy. The initial conditions involved a small trade/GDP ratio, and a highly repressed capital account. At the same time, India had many potential strengths for participating in the global financial markets. These included strong traditions of law and accounting, a long tradition of equity ownership and trading, and an absence of a history of default. ${ }^{19}$

The goals of the reforms of the early 1990s were articulated by the policy makers of the time as comprising three elements:

1. Avoiding debt flows and particularly short term debt flows, which were viewed as being potentially destabilising.

2. Increasing India's trade integration into the world.

3. Spurring Indian growth by harnessing the growing global FDI and portfolio flows.

In the post-war period, two successful "Asian Development Models" are known. The first is the approach of a completely closed capital account, with no FDI and no portfolio flows, which was followed by Japan (1950s-1960s), and Korea and Taiwan (1970s-1980s). There is the alternative approach of encouraging FDI and having restricted portfolio flows, followed by Singapore (1970s-1980s), Malaysia and Thailand (1980s-1990s) and China (1980s). Both these models used substantial rigidity in the currency regime. India appears to have embarked on a different path, with considerable freedom for both FDI and portfolio flows, modern institutional development of securities markets, considerable success in attracting portfolio flows, and a movement towards greater currency flexibility.

India did not engage in 'big bang' liberalisation. The full policy implications of this broad position were worked out through a steady pace of numerous reforms initiatives in the 19922004 period. The present framework of tariffs, restrictions against FDI and restrictions against portfolio flows implies that the reforms agenda on the current account, on FDI and on portfolio flows remains incomplete as of 2004.

Looking back, these goals have been achieved to a significant extent:

1. Net debt flows were at roughly 1\% of GDP in both 1992-93 and 2003-04. Gross debt flows actually dropped sharply, from $13.5 \%$ of GDP in $1992-93$ to $10.6 \%$ in $2003-04$.

2. Trade integration has gone up sharply, with gross current account flows rising from $25 \%$ of GDP in $1992-93$ to $35 \%$ in $2003-04$.

3. FDI and portfolio flows have gone up sharply. India has fared particularly well in the institutional transformation of the equity market, which helped Indian equities obtain acceptance in global portfolios. The experience with FDI flows, while showing strong growth rates when compared with the initial conditions, lags that of other Asian countries, both in absolute terms and when expressed as per cent to GDP.

\footnotetext{
${ }^{19}$ As emphasised in Reinhart \& Rogoff (2004), some countries are "serial defaulters" and pose high risks to foreign sources of capital. India has been through two IMF programs in situations where a fixed exchange rate regime was challenged owing to near-exhaution of reserves (in 1981 and 1991). However, India has never defaulted.
} 
In an open-economy, these three aspects of policy are closely intertwined with the currency regime. India has been in a quest for openness in trade, FDI and portfolio flows, while continuing to have capital controls in most other respects, and trying to have both an independent monetary policy and a pegged exchange rate. There was a very strong consensus about the usefulness of extensive trading by the central bank on the currency market in implementing currency policy. Indeed, issues about the currency regime were not debated in the 1992-2002 period.

As a consequence, India's experience with capital flows is deeply intertwined with India's experience with the currency regime. Capital flows have shaped the currency regime, and the currency regime has shaped capital flows.

Openness on the trade account, FDI and portfolio flows has given economic agents opportunities to express speculative views about currency movements, and thus thrown up new problems in the implementation of pegging. India differs from China in the importance of portfolio flows. Portfolio flows involve robust inflows and outflows. For example, in 2003-04, portfolio inflows were only 1.67 times bigger than portfolio outflows, and gross portfolio flows amounted to 7 per cent of GDP.

Difficulties faced by the central bank in implementing the currency regime have continually influenced the pace of removal of controls on capital flows. In particular, there has been significant policy volatility with respect to debt flows, ranging from periods with governmentsponsored offshore borrowing to periods with sharp restrictions upon offshore borrowing. Similarly, policies on outward capital flows have been ambivalent, and have lacked the consistent direction of reform that was found on the current account, on FDI and on portfolio flows.

The implementation of the currency regime has led to large capital outflows in the form of reserves accumulation by the RBI. This was particularly the case in $2003-04$, when $4.9 \%$ of GDP left the country in this fashion. The total outward flow was larger than this when we take into account other policy tools such as pre-payment of official debt, which were used in 2003-04.

One of the key goals of the reforms of the 1990s was to augment domestic GDP growth by attracting FDI and portfolio flows. In 2003-04, the total net capital inflows of $\$ 20.5$ billion were accompanied by an outward official capital flow of over $\$ 31.4$ billion. This leads to concerns about whether this policy framework has succeded in serving the interests of accelerating GDP growth. India has undoubtedly reaped microeconomic benefits from the new presence of FDI and foreign investors on the equity market. However, a sustainable macroeconomic framework for a current account deficit, and augmenting domestic investment using foreign capital, is not yet in place.

\section{References}

Alfaro, L., Kalemli-Ozcan, S. \& Volosovych, V. (2004), Volatility of capital flows: Bad policies or bad institutions?, Technical report, Harvard Business School and University of Houston.

Bird, G. \& Rajan, R. S. (2002), 'Does FDI guarantee the stability of international capital flows? Evidence from Malaysia', Development Policy Review 20(2), 191-202. 
Calvo, G. A. \& Reinhart, C. M. (2002), 'Fear of floating', Quarterly Journal of Economics CXVII(2), 379-408.

Chinn, M. D. \& Frankel, J. A. (1994), More survey data on exchange rate expectations: More currencies, more horizons, more tests, Technical Report 312, University of California, Santa Cruz.

Dooley, M. P., Folkerts-Landau, D. \& Garber, P. (2003), An essay on the revived Bretton Woods system, Technical Report w9971, NBER.

Fernandez-Arias, E. \& Hausmann, R. (2000), Is FDI a safer form of financing, Technical report, Inter-American Development Bank.

Frankel, J. A. \& Okongwu, C. (1996), 'Liberalised portfolio capital inflows in emerging markets:Sterilisation, expectations, and the incompleteness of interest rate convergence', International Journal of Finance and Economics 1(1).

Frankel, J. \& Wei, S.-J. (1994), Yen bloc or dollar bloc? Exchange rate policies of the East Asian countries, in T. Ito \& A. Krueger, eds, 'Macroeconomic linkage: Savings, exchange rates and capital flows', University of Chicago Press.

Gordon, J. \& Gupta, P. (2003), Portfolio flows in India: Do domestic fundamentals matter?, Technical report, IMF Working Paper No. 03/20.

Gordon, J. \& Gupta, P. (2004), Nonresident deposits in India: In search of return?, Technical report, IMF Working Paper No. 04/48.

Hausmann, R. \& Fernandez-Arias, E. (2000), Foreign direct investment: Good cholesterol?, Technical report, Inter-American Development Bank.

Johnston, B. R. \& Tamirisa, N. T. (1998), Why do countries use capital controls?, Technical Report 98/181, IMF, Washington.

Joshi, V. (2003), 'India and the impossible trinity', The World Economy 26(4), 555-583.

Joshi, V. \& Little, I. (1994), India : Macroeconomics and Political Economy, 1964-1991, Oxford University Press.

Lal, D., Bery, S. \& Pant, D. (2003), 'The real exchange rate,fiscal deficits and capital flows India: 1981-2000', Economic and Political Weekly XXXVIII(47), 4965-4976.

Miniane, J. (2004), 'A new set of measures on capital account restrictions', IMF Staff Papers 51(2), 276-308.

Mohan, R. (1996), The India Infrastructure Report (Expert Group on the Commercialisation of Infrastructure Projects), Committee report, Ministry of Finance.

Panagariya, A. (2005), 'India's trade reform', India Policy Forum 1, 1-57.

Patnaik, I. (2003), India's policy stance on reserves and the currency, Technical report, ICRIER Working Paper No 108.

Patnaik, I. (2005), 'India's experience with a pegged exchange rate', India Policy Forum 1, 189-216.

Patnaik, I. \& Vasudevan, D. (2000), 'Trade misinvoicing and capital flight from India', Journal of International Economic Studies 14, 99-108.

Portes, R. \& Rey, H. (2001), The determinants of cross-border equity flows, Technical report, LBS and Princeton University. 
Reinhart, C. \& Rogoff, K. (2004), Serial default and the "paradox" of rich to poor capital flows, Technical Report 10296, NBER.

Shah, A. \& Thomas, S. (1997), Securities markets, in K. S. Parikh, ed., 'India Development Report 1997', Oxford University Press, chapter 10, pp. 167-192.

Shah, A. \& Thomas, S. (2000), 'David and Goliath: Displacing a primary market', Journal of Global Financial Markets 1(1), 14-21.

Shah, A. \& Thomas, S. (2003a), Policy issues in Indian securities markets, in A. Krueger \& S. Z. Chinoy, eds, 'Reforming India's External, Financial and Fiscal Policies', Stanford Studies in International Economics and Development, Stanford University Press, chapter 4, pp. 129-147.

Shah, A. \& Thomas, S. (2003b), Securities market efficiency, in J. A. Hanson, P. Honohan \& G. Majnoni, eds, 'Globalization and national financial systems', The World Bank and Oxford University Press, chapter 6, pp. 145-175.

Sobol, D. M. (1998), 'Foreign ownership of U.S. treasury securities: What the data show and do not show', FRBNY Current Issues in Economics and Finance 4(5).

Venables, W. N. \& Ripley, B. D. (2002), Modern applied statistics with S, 4th edn, Springer. 